\title{
A new high-resolution pollen sequence at Lake Van, Turkey: insights into penultimate interglacial-glacial climate change on vegetation history
}

\author{
Nadine Pickarski and Thomas Litt \\ University of Bonn, Steinmann Institute for Geology, Mineralogy and Paleontology, Bonn, Germany \\ Correspondence to: Nadine Pickarski (pickarski@uni-bonn.de)
}

Received: 8 December 2016 - Discussion started: 19 December 2016

Revised: 11 April 2017 - Accepted: 12 May 2017 - Published: 14 June 2017

\begin{abstract}
A new detailed pollen and oxygen isotope record of the penultimate interglacial-glacial cycle, corresponding to the marine isotope stage (MIS) 7-6, has been generated from the Ahlat Ridge (AR) sediment core at Lake Van, Turkey. The presented Lake Van pollen record (ca. 250.2$128.8 \mathrm{ka}$ ) displays the highest temporal resolution in this region with a mean sampling interval of $\sim 540$ years.

The integration of all available proxies shows three temperate intervals of high effective soil moisture availability. This is evidenced by the predominance of steppe-forested landscapes (oak steppe-forest) similar to the present interglacial vegetation in this sensitive semiarid region between the Black Sea, the Caspian Sea, and the Mediterranean Sea.

The wettest and warmest stage, as indicated by highest temperate tree percentages, can be broadly correlated with MIS 7c, while the amplitude of the tree population maximum during the oldest penultimate interglacial (MIS 7e) appears to be reduced due to warm but drier climatic conditions. The detailed comparison of the penultimate interglacial complex (MIS 7) to the last interglacial (Eemian, MIS 5e) and the current interglacial (Holocene, MIS 1) provides a vivid illustration of possible differences in the successive climatic cycles. Intervening periods of treeless vegetation can be correlated with MIS 7d and 7a, in which open landscapes favor local erosion and detrital sedimentation. The predominance of steppe elements (e.g., Artemisia, Chenopodiaceae) during MIS 7d indicates very dry and cold climatic conditions. In contrast, the occurrence of higher temperate tree percentages (mainly deciduous Quercus) throughout MIS 7b points to relatively humid and mild conditions, which is in agreement with other pollen sequences in southern Europe.
\end{abstract}

Despite the general dominance of dry and cold desertsteppe vegetation during the penultimate glacial (broadly equivalent to MIS 6), this period can be divided into two parts: an early stage (ca. 193-157 ka) with higher oscillations in tree percentages and a later stage (ca. 157-131 ka) with lower tree percentages and subdued oscillations. This subdivision of the penultimate glacial is also seen in other pollen records from southern Europe (e.g., MD01-2444 and I-284; Margari et al., 2010; Roucoux et al., 2011). The occurring vegetation pattern is analogous to the division of MIS 3 and MIS 2 during the last glacial in the same sediment sequence. Furthermore, we are able to identify the MIS 6e event (ca. $179-159 \mathrm{ka}$ ) as described in marine pollen records, which reveals clear climate variability due to rapid alternation in the vegetation cover.

In comparison with long European pollen archives, speleothem isotope records from the Near East, and global climate parameters (e.g., insolation, atmospheric $\mathrm{CO}_{2}$ content), the new high-resolution Lake Van record presents an improved insight into regional vegetation dynamics and climate variability in the eastern Mediterranean region.

\section{Introduction}

The long continental pollen record of Lake Van (Turkey) contributes significantly to the picture of long-term interglacialglacial terrestrial vegetation history and climate conditions in the Near East (Litt et al., 2014). Based on millennial-scale time resolution (between ca. 1 and $4 \mathrm{ka}$ ), the 600000 year pollen record already shows a general pattern of alternating periods of forested and treeless landscapes that clearly re- 


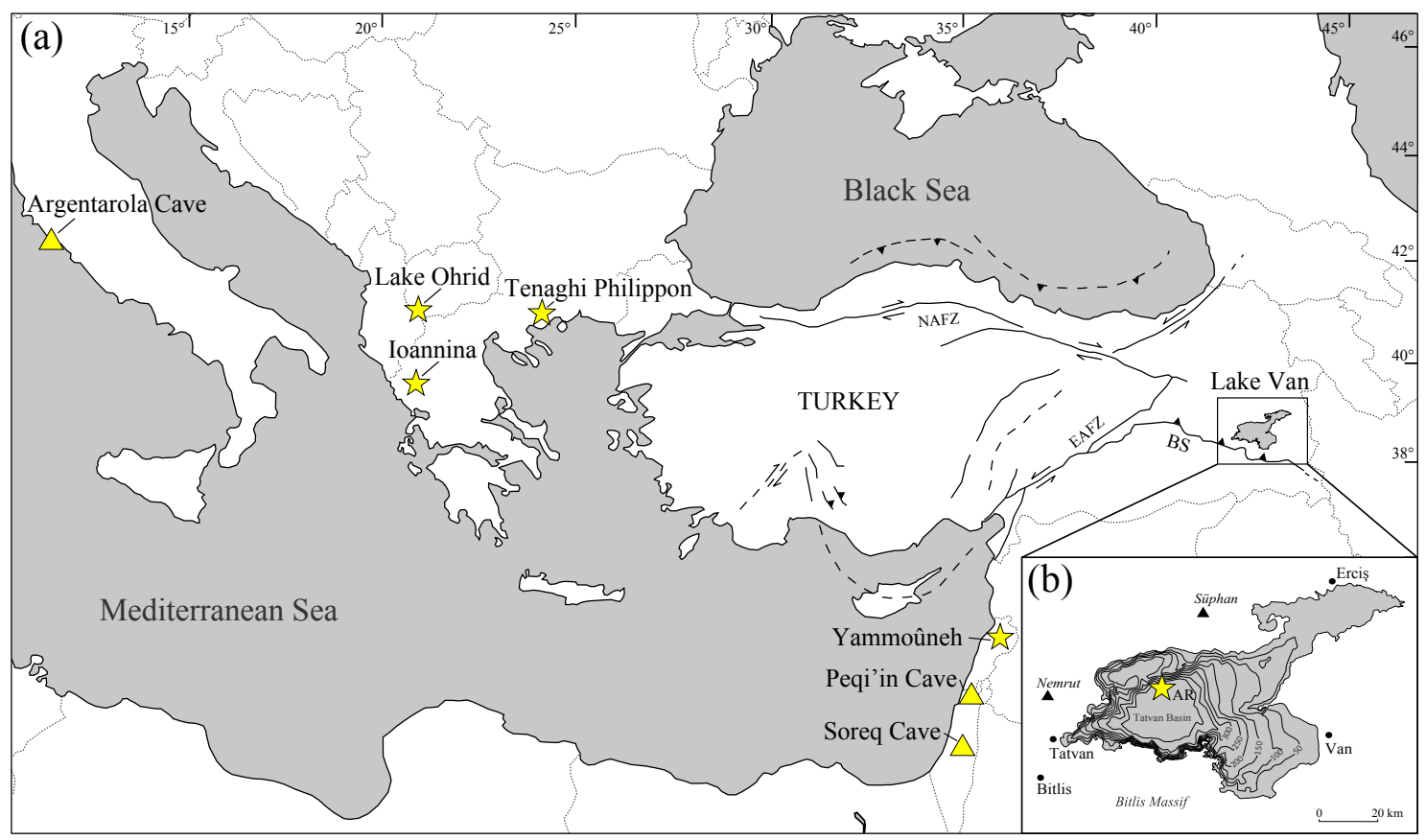

Figure 1. Map of the eastern Mediterranean region showing major tectonic structures in Turkey. (a) Location of key Mediterranean and Near East pollen sites (stars) and speleothem records (triangle) mentioned in the text. (b) Bathymetry of Lake Van including the Ahlat Ridge drill site (AR; star). The black triangle indicates the positions of the active Nemrut and Süphan volcanoes. NAFZ: North Anatolian Fault zone; EAFZ: East Anatolian Fault zone; BS: Bitlis Suture.

sponds to the Milankovitch-driven global climatic changes (Berger, 1978; Martinson et al., 1987). In that study, the Lake Van pollen record demonstrated the potential ecological sensitivity for paleoclimate investigations that bridge the southern European and Near East climate realms. Since then, highresolution multi-proxy investigations of the Lake Van sedimentary record have allowed the systematic documentation of different climatic phases throughout the last interglacialglacial cycle (Pickarski et al., 2015a, b).

To date, little attention has been focused on characterizing terrestrial sedimentary archives beyond $130 \mathrm{ka}$. In particular, the detailed vegetation response to climatic and environmental changes in the Near East during the penultimate interglacial-glacial cycle (marine isotope stage (MIS) 7 to 6) has not been thoroughly investigated.

In this context, we present new high-resolution pollen and oxygen isotope data from the Ahlat Ridge composite sequence over the penultimate interglacial-glacial cycle (between ca. 242.5 and $131.2 \mathrm{ka}$ ). We have added our recent results to the existing low-resolution palynological and isotope data from Lake Van published by Litt et al. (2014) and Kwiecien et al. (2014). This enables us to provide new detailed documentation of multiple vegetation and environmental changes in eastern Anatolia with a centennial- to millennial-scale temporal resolution of $\sim 180$ to 780 years. Our record is placed in its regional context by the comparison with several archives from the Mediterranean region, e.g., Lake Ohrid (between the former Yugoslav republics of Macedonia and Albania; Sadori et al., 2016), the Ioannina basin (NW Greece; Frogley et al., 1999; Roucoux et al., 2008, 2011; Tzedakis et al., 2003a), Tenaghi Philippon (NE Greece; Tzedakis et al., 2003b, 2006), and the Yammoûneh basin (Lebanon; Gasse et al., 2011, 2015).

In our study, we address the following questions:

1. What kind of regional vegetation occurred during the penultimate interglacial complex? Is the regional vegetation pattern of the oldest penultimate interglacial comparable to the last interglacial (Eemian) and current warm stage (Holocene)?

2. What processes characterized the climatic and environmental responses during the penultimate glacial? Is this vegetation history similar to the millennial-scale variability recorded during the last glacial in the same sequence?

3. Does the Lake Van vegetation history correlate with other existing long pollen records from southern Europe? What are the influencing factors of environmental change in the Near East?

\section{Site description}

Lake Van is situated on the eastern Anatolian high plateau at $1648 \mathrm{~m}$ a.s.l. (meters above sea level; Fig. 1) in Turkey. 
Table 1. Present-day climate data at Lake Van (see Fig. 1 for the location). Data were provided by the Turkish State Meteorological Service (observation period: 1975-2008).

\begin{tabular}{|c|c|c|c|c|c|c|c|c|c|}
\hline \multirow[t]{2}{*}{ Station } & \multicolumn{3}{|c|}{ Coordinates } & \multicolumn{3}{|c|}{ Mean temperature $\left({ }^{\circ} \mathrm{C}\right)$} & \multicolumn{3}{|c|}{ Mean precipitation $(\mathrm{mm})$} \\
\hline & $\begin{array}{l}\text { Latitude } \\
\left({ }^{\circ} \mathrm{N}\right)\end{array}$ & $\begin{array}{l}\text { Longitude } \\
\left({ }^{\circ} \mathrm{E}\right)\end{array}$ & $\begin{array}{r}\text { Altitude } \\
\text { (m a.s.l.) }\end{array}$ & Jan & July & Year & Jan & July & Year \\
\hline Bitlis & 38.400 & 42.109 & 1551 & -2.0 & 22.0 & 9.4 & 161 & 5 & 1232 \\
\hline Tatvan & 38.502 & 42.283 & 1690 & -3.2 & 21.9 & 8.7 & 95 & 7 & 816 \\
\hline Erciş & 39.029 & 43.358 & 1750 & -6.0 & 21.8 & 7.7 & 31 & 7 & 421 \\
\hline Van & 38.502 & 43.374 & 1661 & -4.0 & 22.2 & 9.0 & 35 & 4 & 385 \\
\hline
\end{tabular}

The deep terminal alkaline lake $\left(\sim 3574 \mathrm{~km}^{2}\right.$; max. depth $>450 \mathrm{~m}$ ) occupies the eastern continuation of the Muş basin developed in the collision zone between the Arabian and Eurasian plates at $\sim 13 \mathrm{Ma}$ (Reilinger et al., 2006). The regional volcanism of the Nemrut and Süphan volcanoes (at 2948 and 4058 m a.s.l., respectively; Fig. 1b), subaquatic hydrothermal exhalations, and tectonic activities are still active today, as evidenced by the $M 7.2$ Van earthquake that occurred on 23 October 2011 (Altiner et al., 2013).

The present-day climate at Lake Van is continental (summer-dry and winter-wet) with a mean annual temperature of $>9{ }^{\circ} \mathrm{C}$ and mean annual precipitation between 400 and $1200 \mathrm{~mm} \mathrm{yr}^{-1}$ (Turkish State Meteorological Service, 1975-2008; Table 1). In general, eastern Anatolia receives most of its moisture in winter due to the Cyprus low-pressure system within the eastern Mediterranean Sea (Giorgi and Lionello, 2008). At Lake Van, rainfall decreases sharply from southwest (ca. $1232 \mathrm{~mm} \mathrm{yr}^{-1}$ in Bitlis) to northeast (ca. $421 \mathrm{~mm} \mathrm{yr}^{-1}$ in Erciş; Table 1) due to the orographic effects of the NWW-SEE Bitlis Massif running parallel to the southern shore of the lake (Fig. 1).

Due to the diverse topography at Lake Van, local variations in moisture availability and temperature are quite pronounced and reflected in the modern vegetation distribution. At present, the vegetation cover around Lake Van has been altered by agricultural and pastoral activities. According to Zohary (1973), the southern mountain slopes are covered by the Kurdo-Zagrosian oak steppe-forest belt containing Quercus brantii, $Q$. ithaburensis, $Q$. libani, $Q$. robur, $Q$. petraea, Juniperus excelsa, and Pistacia atlantica. This oak steppeforest has also been described as a "mixed formation of cold-deciduous broad-leaved montane woodland and xeromorphic dwarf-shrublands" by Frey and Kürschner (1989). In contrast, the dwarf shrub steppes of the Irano-Turanian floral province are dominated by Artemisietea fragrantis anatolica steppe, different species of Chenopodiaceae, and grasses with some sub-Euxinian oak forest remnants (Frey and Kürschner, 1989; van Zeist and Bottema, 1991; Zohary, 1973).

\section{Material and methods}

\subsection{Ahlat Ridge composite record}

The sediment archive AR (Ahlat Ridge; $38.667^{\circ} \mathrm{N}$, $42.669^{\circ} \mathrm{E}$ at ca. $357 \mathrm{~m}$ water depth; Fig. 1) was collected during the ICDP drilling campaign (International Continental Scientific Drilling Program, www.icdp-online.org) PALEOVAN in summer 2010 (Litt and Anselmetti, 2014; Litt et al., 2012). The ca. 219 mcblf (meter composite below lake floor) record contains a well-preserved partly laminated or banded sediment sequence intercalated by several volcanic and event layers (e.g., turbidites; Stockhecke et al., 2014b). For a further detailed description of the Lake Van lithology, we refer to Stockhecke et al. (2014b).

In this paper, we focus on a $60.1 \mathrm{~m}$ sediment section from 117.19 to 57.10 mcblf representing the time span from ca. 250.16 to $128.79 \mathrm{ka}$. In this section, we combine new pollen and isotope data with the existing low-resolution pollen record published by Litt et al. (2014) and oxygen isotope data derived from bulk sediments $\left(\delta^{18} \mathrm{O}_{\text {bulk }}\right)$ analyzed by Kwiecien et al. (2014).

\subsection{Chronology}

The analytical approaches applied for the Lake Van chronology have previously been published in detail in Stockhecke et al. (2014a) All ages are given in thousands of years before present (ka), where 0 before present is defined as 1950 AD. Marine isotope stage (MIS) boundaries follow Lisiecki and Raymo (2004). The main results of the construction of the age-depth model are briefly summarized here.

For the investigated period, the age-depth model is based on independent proxy records, e.g., the calcium and potassium element ratio $(\mathrm{Ca} / \mathrm{K})$ measured by high-resolution $\mathrm{X}$ ray fluorescence (XRF; details in Kwiecien et al., 2014), total organic carbon (TOC; details in Stockhecke et al., 2014b), and pollen data (Litt et al., 2014). For the climatostratigraphic alignment of the presented Lake Van sequence, the proxy records were visually synchronized to the speleothembased synthetic Greenland record $\left(\mathrm{GL}_{\mathrm{T}-\mathrm{syn}}\right.$ from 116 to $400 \mathrm{ka}$; Barker et al., 2011). The identifications of TOC-rich sediments containing high $\mathrm{Ca} / \mathrm{K}$ intensities and increased 
AP (arboreal pollen) values at the onset of interstadials and interglacials were aligned to the interstadial or interglacial onsets of the synthetic Greenland record by using "age control points". Here, the correlation points of the Lake Van sedimentary record have been mainly defined by abiotic proxies (i.e., TOC) caused by a higher time resolution of this data set in comparison to the pollen samples available during that time. Even though we present a high-resolution pollen record in this paper, leads and lags between different biotic and abiotic proxies related to climate events have to be taken into account.

Furthermore, the age-depth model of the presented section (117.2-57.1 mcblf; $250.2-128.8 \mathrm{ka})$ was improved by adding two paleomagnetic time markers (relative paleointensity minima, RPI) analyzed by Vigliotti et al. (2014) at $\sim 213-210 \mathrm{ka}$ (Pringle Falls event; Thouveny et al., 2004) and at $\sim 240-238 \mathrm{kaBP}$ (Mamaku event; Thouveny et al., 2004). In addition, three reliable ${ }^{40} \mathrm{Ar} /{ }^{39} \mathrm{Ar}$ ages of the single-crystal dated tephra layer at ca. $161.9 \pm 3.3 \mathrm{ka}(\mathrm{V}-114$ at $71.48 \mathrm{mcblf})$, ca. $178.0 \pm 4.4 \mathrm{ka}(\mathrm{V}-137$ at $82.29 \mathrm{mcblf})$, and ca. $182 \mathrm{ka}$ (V-144 at 87.62 mcblf; Stockhecke et al., 2014b) are used to refine the age-depth model.

\subsection{Palynological analysis}

For the new high-resolution pollen analysis, 193 subsamples were taken at $20 \mathrm{~cm}$ intervals. The temporal resolution between each pollen sample, derived from the present agedepth model, ranges from $\sim 180$ to 780 years (mean temporal resolution ca. 540 years).

Subsamples with a volume of $4 \mathrm{~cm}^{3}$ were prepared using the standard palynological procedures outlined by Faegri and Iversen (1989) and improved at the University of Bonn. This preparation includes treatment with $10 \%$ hot hydrochloric acid $(\mathrm{HCl} ; 10 \mathrm{~min}), 10 \%$ hot potassium hydroxide $(\mathrm{KOH}$; $25 \mathrm{~min}$ ), $39 \%$ hydrofluoric acid (HF; 2 days), glacial acetic acid $\left(\mathrm{C}_{2} \mathrm{H}_{4} \mathrm{O}_{2}\right)$, hot acetolysis with 1-part concentrated sulfuric acid $\left(\mathrm{H}_{2} \mathrm{SO}_{4}\right)$ and 9-parts concentrated acetic anhydrite $\left(\mathrm{C}_{4} \mathrm{H}_{6} \mathrm{O}_{3}\right.$; max. $\left.3 \mathrm{~min}\right)$, and ultrasonic sieving to concentrate the palynomorphs. In order to calculate the pollen and micro-charcoal $(>20 \mu \mathrm{m})$ concentrations (grains cm${ }^{-3}$ and particles $\mathrm{cm}^{-3}$, respectively), tablets of Lycopodium clavatum spore (batch no. 483216 , batch no. 177745 ) were added to each sample (Stockmarr, 1971). In all spectra, the average of $\sim 540$ pollen grains was counted in each sample using a Zeiss Axio Lab.A1 light microscope. Terrestrial pollen taxa were identified to the lowest possible taxonomic group using the recent pollen reference collections of the Steinmann Institute (Department of Paleobotany) as well as Beug (2004), Moore et al. (1991), Punt (1976), and Reille (1999, 1998, 1995). Furthermore, we followed the taxonomic nomenclature according to Berglund and Ralska-Jasiewiczowa (1986).

Pollen results are given as a percentage and concentration diagram of selected taxa (Fig. 2). The diagram includes the total arboreal pollen (AP; trees and shrubs) and non-arboreal pollen (NAP; herbs) ratio (100\% terrestrial pollen sum). In order to evaluate lake surface conditions, dinoflagellate cysts and green algae (e.g., Pseudopediastrum boryanum, $P$. kawraiskyi, Pediastrum simplex, Monactinus simplex) were counted on the residues from preparation for palynological analyses. Percent calculation, cluster analysis (CONISS; sum of square roots) to define pollen assemblage zones (PAZs), and construction of the pollen diagram were carried out with TILIA software (version 1.7.16; (01991-2011 Eric C. Grimm).

The complete palynological data set is available on the Pangaea database (www.pangaea.de; doi:10.1594/PANGAEA.871228).

\subsection{Oxygen isotope analysis}

Stable oxygen isotope measurements $\left(\delta^{18} \mathrm{O}_{\text {bulk }}\right)$ were made on bulk sediment samples with an authigenic carbonate content of $\sim 30 \%\left(\mathrm{CaCO}_{3}\right)$. Similar to the pollen analysis, 193 subsamples were taken for the new high-resolution isotope record at $20 \mathrm{~cm}$ intervals within the penultimate interglacialglacial cycle. Before measurements were made, the samples were dried at ca. $40^{\circ} \mathrm{C}$ for at least $48 \mathrm{~h}$ and homogenized by a mortar. The isotope analyses were carried out at the Leibnitz Laboratory at the University of Kiel using a Finnigan GasBench II with a carbonate option coupled to a DELTA plus XL IRMS (Thermo Fisher Scientific, Waltham, MA, USA).

All isotope values are reported in per mil (\%o), relative to the Vienna Pee Dee Belemnite (VPDB) standard. The standard deviation of the analyses of replicate samples is $0.02 \%$ o for $\delta^{18} \mathrm{O}_{\text {bulk }}$.

\section{New data from the Lake Van sequence}

\subsection{The high-resolution pollen record}

The new palynological results from the penultimate interglacial-glacial cycle are illustrated in a simplified pollen diagram (Fig. 2). The main characteristics of each pollen zone and the interpretation of their inferred dominant vegetation types are summarized in Table 2.

The low-resolution pollen sequence, shown in Litt et al. (2014), has already been divided into six pollen assemblage superzones (PAS IIIc, IV, Va, Vb, Vc, VI). This study followed the criteria for the classification of the pollen superzones as described in Tzedakis (1994, and references therein). Based on the new detailed high-resolution pollen sequence compared to the record in Litt et al. (2014), the PAS $\mathrm{IV}, \mathrm{Va}$, and $\mathrm{Vc}$ can now be further subdivided into 13 pollen assemblage zones (PAZs).

The pollen diagram provides a broad view of alternation between regional open deciduous oak steppe-forest and treeless desert-steppe vegetation. We were able to recognize three main phases (PAZ Va1, Va3, and during Vc2 and $\mathrm{Vc} 3$ ) in which total arboreal pollen percentages are above 


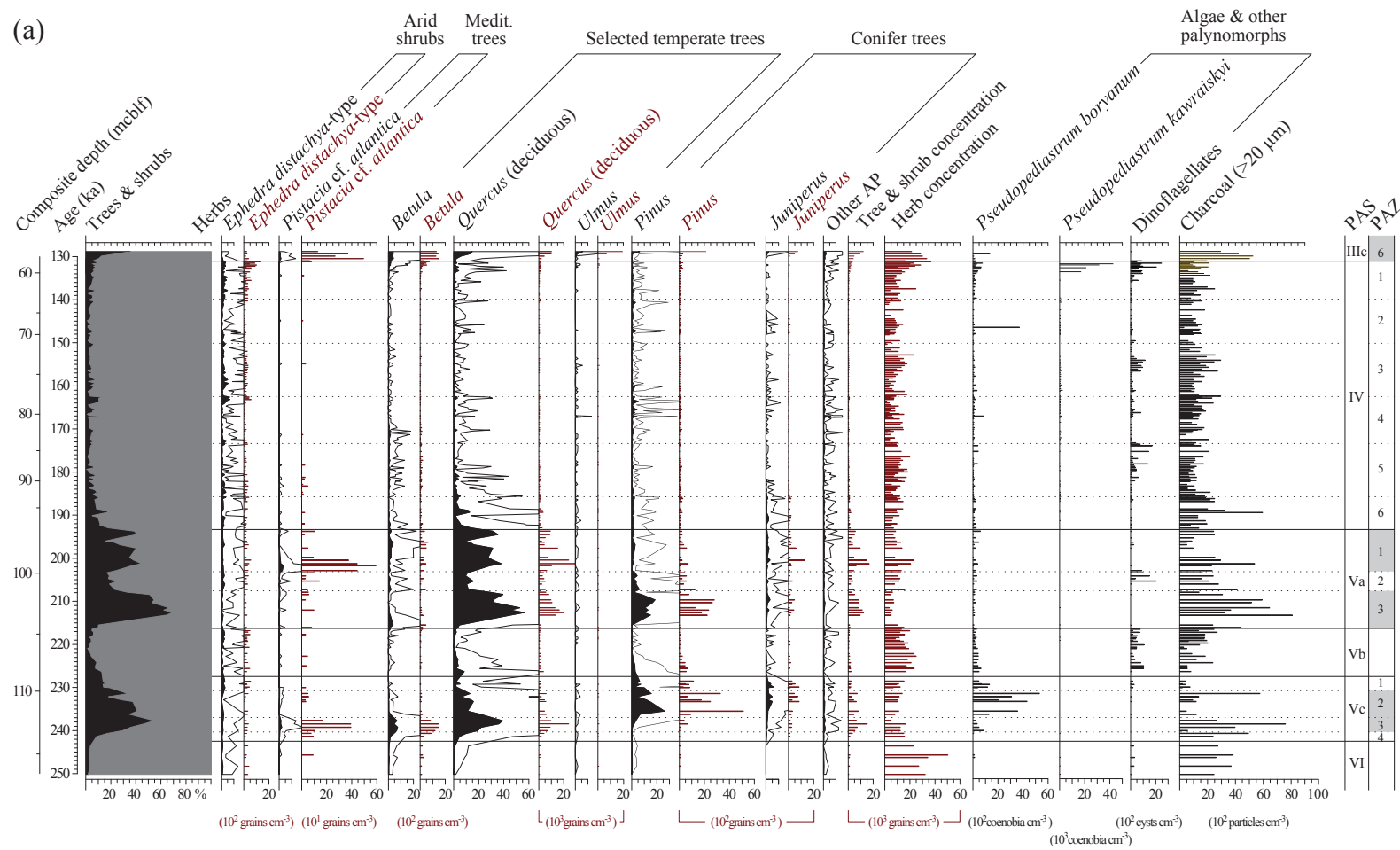

(b)
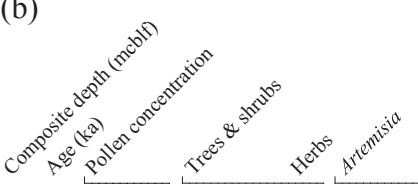

Steppic herbs

Other selected herbs

Aquatic herbs
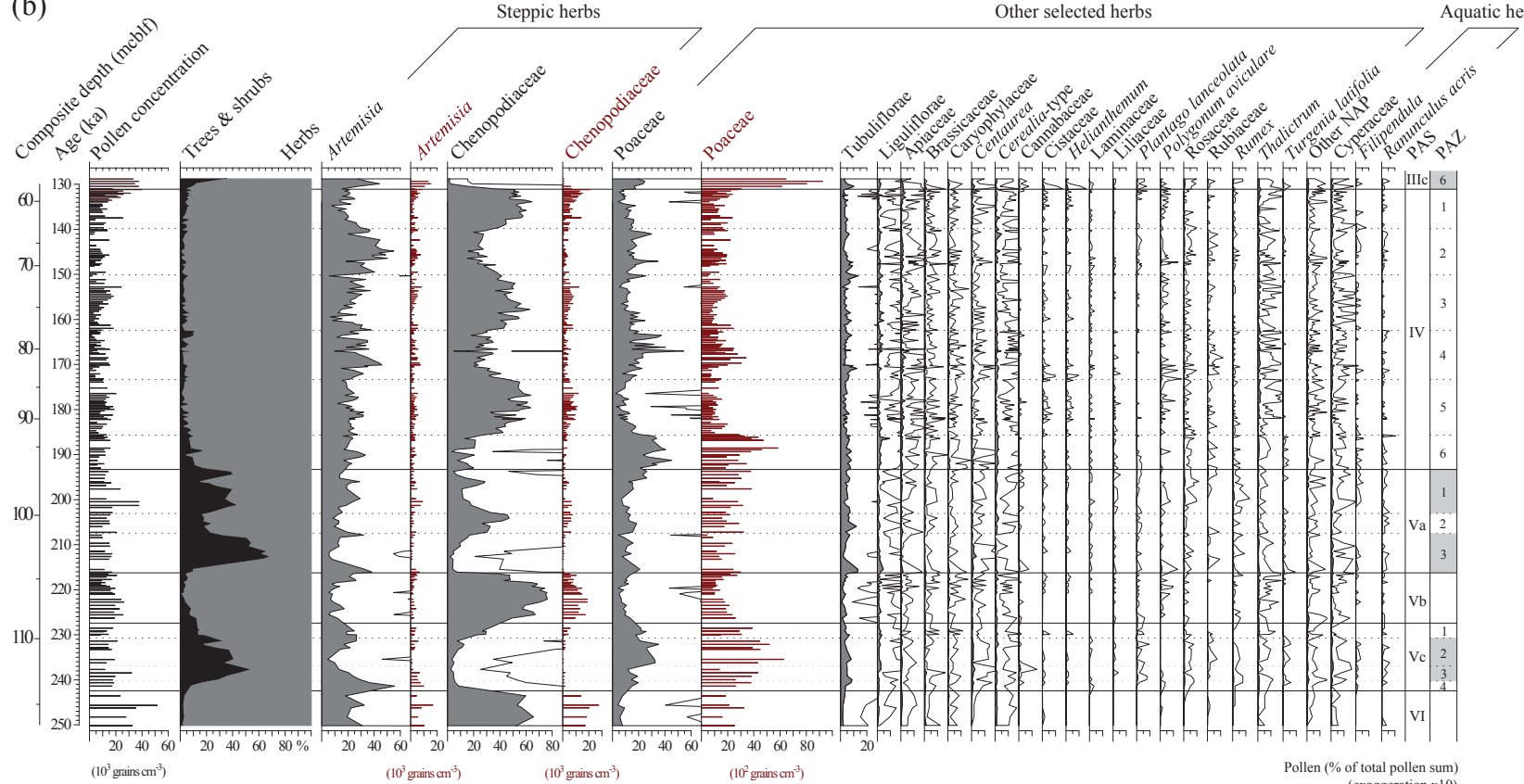

Figure 2. Pollen diagram inferred from Lake Van sediments plotted against composite depth (mcblf) and age (ka). (a) Selected arboreal pollen abundances are expressed as percentages and concentrations of the pollen sum (black curves), which excludes bryophytes, pteridophytes, and aquatic taxa. Rare taxa are summed and presented as "other AP”. Selected arboreal pollen concentration (grains per $\mathrm{cm}^{3}$; red bars) is also given. Concentrations of green algae (Pseudopediastrum boryanum, P. kawraiskyi; coenobia per $\mathrm{cm}^{3}$; black bars), dinoflagellates (cysts per $\mathrm{cm}^{3}$; black bars), and charcoal particles ( $>20 \mu \mathrm{m}$, particles per $\mathrm{cm}^{3}$; black bars) are presented. (b) Selected pollen percentages for non-arboreal taxa and key aquatic herbs (gray curves). Percentages and concentrations are calculated as for arboreal pollen. Rare taxa are summed as "other NAP”. Pollen assemblage superzones (PAS) and zones (PAZ; gray dashed lines) are indicated on the right and described in Table 2. Intervals characterized by oak steppe-forest ( $\mathrm{AP}>30 \%$ ) are marked in each diagram (gray box). An exaggeration of the pollen curves $(\times 10$; white curves) is used to show low variations in pollen percentages. 
Table 2. Main palynological characteristics of the Lake Van pollen assemblage superzones (PAS) and zones (PAZ) with composite depth (mcblf), age (ka), criteria for the lower boundary, components of the pollen assemblage (AP: arboreal pollen, NAP: non-arboreal

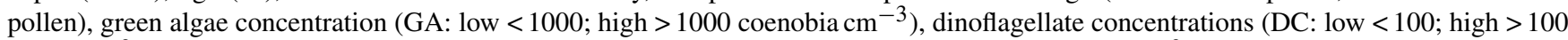
cysts $\mathrm{cm}^{-3}$ ), charcoal concentrations (CC: low <2000; moderate 2000-4000; high > 4000 particles $\mathrm{cm}^{-3}$ ), and their inferred dominant vegetation type during the penultimate interglacial-glacial cycle. Marine isotope stages after Lisiecki and Raymo (2004) are shown on the right.

\begin{tabular}{|c|c|c|c|c|c|c|c|}
\hline PAS & PAZ & $\begin{array}{l}\text { Compos } \\
\text { depth } \\
\text { (mcblf) }\end{array}$ & $\begin{array}{l}\text { Age } \\
\text { (ka) }\end{array}$ & $\begin{array}{l}\text { Criteria for } \\
\text { lower boundary }\end{array}$ & $\begin{array}{l}\text { Main palynological characteristics } \\
\text { (minimum to maximum in } \% \text { ) }\end{array}$ & $\begin{array}{l}\text { Dominant } \\
\text { vegetation } \\
\text { type }\end{array}$ & MIS \\
\hline IIIc & 6 & $\begin{array}{l}57.10- \\
58.09\end{array}$ & $\begin{array}{l}128.80- \\
131.21\end{array}$ & $\begin{array}{l}\text { Occurrence } \\
\text { Pistacia }\end{array}$ & $\begin{array}{l}\text { AP: Betula }(2-4 \%) \text {, dec. Quercus }(1- \\
13 \%), \text { Ephedra distachya-type }(0-3 \%) \text {, } \\
\text { Ulmus }(0-2 \%) \text {, Juniperus }(0-1 \%), \text { Pinus } \\
(0-1 \%) \text {, Pistacia cf. atlantica }(0-1 \%) \\
\text { NAP: Artemisia }(16-49 \%) \text {, Poaceae }(7- \\
25 \%) \text {, Chenopodiaceae }(2-52 \%) \\
\text { GA low, DC low, CC moderate to high }\end{array}$ & $\begin{array}{l}\text { Steppe } \\
\text { taxa be- } \\
\text { come less } \\
\text { widespread, } \\
\text { giving way } \\
\text { to open } \\
\text { grassland }\end{array}$ & $5 \mathrm{e}$ \\
\hline \multirow[t]{4}{*}{ IV } & 1 & $\begin{array}{l}58.09- \\
63.25\end{array}$ & $\begin{array}{l}131.21- \\
139.87\end{array}$ & $\begin{array}{l}\text { Chenopodiaceae } \\
>40 \%\end{array}$ & $\begin{array}{l}\text { Low AP (2-8\%); increased frequencies } \\
\text { of Ephedra distachya-type (1-5\%); dec. } \\
\text { Quercus, Betula, Pinus, and Juniperus are } \\
\text { abundant at low level } \\
\text { NAP: Chenopodiaceae (39-64\%) show } \\
\text { high values at the top, while Artemisia } \\
(8-29 \%) \text { abundances decline; moderate } \\
\text { Poaceae percentages } \\
\text { GA low, DC low, CC low to moderate }\end{array}$ & $\begin{array}{l}\text { Open } \\
\text { desert- } \\
\text { steppe } \\
\text { vegetation }\end{array}$ & 6 \\
\hline & 2 & $\begin{array}{l}63.25- \\
71.50\end{array}$ & $\begin{array}{l}139.87- \\
150.14\end{array}$ & $\begin{array}{l}\text { Chenopodiaceae } \\
<40 \%\end{array}$ & $\begin{array}{l}\text { Low AP }(1-7 \%) \text {; temperate trees are } \\
\text { present at low level } \\
\text { NAP: expansion of Artemisia contin- } \\
\text { ues and peaks in the middle of the } \\
\text { zone }(54 \%) \text {; Chenopodiaceae percent- } \\
\text { ages drop to } 15-41 \% \text {; moderate Poaceae } \\
\text { values }(11-34 \%) \\
\text { GA low with a single peak at } 146.4 \mathrm{ka} \text { (ca. } \\
\left.3700 \text { coenobia } \mathrm{cm}^{-3}\right) \text {, DC low, CC low }\end{array}$ & $\begin{array}{l}\text { Productive } \\
\text { dwarf } \\
\text { shrub } \\
\text { steppe } \\
\text { vegetation }\end{array}$ & \\
\hline & 3 & $\begin{array}{l}71.50- \\
77.72\end{array}$ & $\begin{array}{l}150.14- \\
162.49\end{array}$ & $\begin{array}{l}\text { Chenopodiaceae } \\
>40 \% \text {; decrease } \\
\text { Quercus }\end{array}$ & $\begin{array}{l}\text { AP: dec. Quercus, Betula, Pinus, and } \\
\text { Juniperus are continuously present at } \\
\text { low level }(2-8 \%) \text {; increase in Ephedra } \\
\text { distachya-type }(1-6 \%) \\
\text { NAP: predominance of Chenopodiaceae } \\
(33-62 \%) ; \text { Artemisia }(6-38 \%) \text { shows } \\
\text { moderate values with increasing trend } \\
\text { towards the top, Poaceae continuously } \\
\text { present at } \sim 13 \% \\
\text { GA high to low at the end of the zone, DC } \\
\text { low to high, CC low to moderate }\end{array}$ & $\begin{array}{l}\text { Open } \\
\text { desert- } \\
\text { steppe } \\
\text { vegetation }\end{array}$ & \\
\hline & 4 & $\begin{array}{l}77.72- \\
83.84\end{array}$ & $\begin{array}{l}162.49- \\
173.38\end{array}$ & $\begin{array}{l}\text { Chenopodiaceae } \\
<40 \% \text {; increase } \\
\text { Quercus }\end{array}$ & $\begin{array}{l}\text { Low AP (1-14\%); moderate dec. Quer- } \\
\text { cus }(0-3 \%) \text {; decrease in Betula }(0-2 \%) \text {, } \\
\text { while Pinus }(0-5 \%) \text { and Juniperus }(0- \\
1 \%) \text { percentages increase towards the top } \\
\text { NAP: predominance of Artemisia (10- } \\
46 \%) \text { and Poaceae ( } 8-54 \%) \text {; Chenopodi- } \\
\text { aceae abundances (5-40\%) are reduced } \\
\text { GA low to high, DC low, CC low with } \\
\text { moderate peaks }\end{array}$ & $\begin{array}{l}\text { Fluctuation } \\
\text { between } \\
\text { open } \\
\text { desert- } \\
\text { steppe and } \\
\text { grassland } \\
\text { scattered } \\
\text { with tem- } \\
\text { perate } \\
\text { trees }\end{array}$ & \\
\hline
\end{tabular}


Table 2. Continued.

\begin{tabular}{|c|c|c|c|c|c|c|c|}
\hline PAS & PAZ & $\begin{array}{l}\text { Composite } \\
\text { depth } \\
\text { (mcblf) }\end{array}$ & $\begin{array}{l}\text { Age } \\
\text { (ka) }\end{array}$ & $\begin{array}{l}\text { Criteria for } \\
\text { lower boundary }\end{array}$ & $\begin{array}{l}\text { Main palynological characteristics } \\
\text { (minimum to maximum in \%) }\end{array}$ & $\begin{array}{l}\text { Dominant } \\
\text { vegetation } \\
\text { type }\end{array}$ & MIS \\
\hline & 5 & $\begin{array}{l}83.84- \\
93.51\end{array}$ & $\begin{array}{l}173.38- \\
185.74\end{array}$ & $\begin{array}{l}\text { Chenopodiaceae } \\
>40 \%\end{array}$ & $\begin{array}{l}\text { AP }(1-9 \%) \text { decrease continuously } \\
\text { throughout the zone, mainly by dec. } \\
\text { Quercus }(0-4 \%) \\
\text { NAP: base marked by a pronounced } \\
\text { expansion of Chenopodiaceae (33-64\%); } \\
\text { Artemisia continues from previous zone } \\
\text { with max. } 32 \% \text {, while Poaceae decrease } \\
\text { (3-18\%) } \\
\text { GA low, DC low to high towards the top, } \\
\text { CC low }\end{array}$ & $\begin{array}{l}\text { Change } \\
\text { from } \\
\text { grassland } \\
\text { to desert- } \\
\text { steppe } \\
\text { vegetation } \\
\text { at the end } \\
\text { of the zone }\end{array}$ & \\
\hline & 6 & $\begin{array}{l}93.51- \\
97.02\end{array}$ & $\begin{array}{l}185.74- \\
193.36\end{array}$ & $\begin{array}{l}\text { Decrease Quer- } \\
\text { cus; increase } \\
\text { Poaceae }\end{array}$ & $\begin{array}{l}\text { Reduction in AP; still abundant: dec. } \\
\text { Quercus }(1-31 \%) \text {, Betula }(0-2 \%) \text {, and } \\
\text { Ulmus }(<1 \%) \text {; moderate conifer trees } \\
\text { with small oscillations; disappearance of } \\
\text { Pistacia cf. atlantica } \\
\text { NAP: increase in Poaceae }(21-45 \%) \text {; } \\
\text { steppic herbs continue to be moderate } \\
\text { GA low, DC low, CC low to moderate, } \\
\text { peak at } 189.4 \mathrm{ka}\end{array}$ & $\begin{array}{l}\text { Open } \\
\text { grass- } \\
\text { lands with } \\
\text { scattered } \\
\text { temperate } \\
\text { trees }\end{array}$ & \\
\hline \multirow[t]{3}{*}{$\mathrm{Va}$} & 1 & $\begin{array}{l}97.02- \\
99.88\end{array}$ & $\begin{array}{l}193.36- \\
203.11\end{array}$ & $\begin{array}{l}\text { Increase AP; } \\
\text { peak Pistacia }\end{array}$ & $\begin{array}{l}\text { High AP (24-44\%), e.g., dec. Quercus } \\
(8-38 \%) \text {, increasing values of Betula (0- } \\
4 \%) \text {, Pinus }(0-3 \%) \text {, and Juniperus ( } 0- \\
3 \%) \text {; peak of Pistacia cf. atlantica (ca. } \\
3 \%) \text { at the beginning; high tree concen- } \\
\text { tration ( }>3000 \text { grains } \mathrm{cm}^{-3} \text { ) } \\
\text { NAP: moderate percentages of steppic } \\
\text { herbs (Artemisia } 13-29 \% \text { and Chenopo- } \\
\text { diaceae } 11-33 \%) \text { with significant peak of } \\
\text { NAP }(85 \%) \text { near the base } \\
\text { GA low, DC low, CC low to moderate } \\
\text { with one single high peak at } 201.3 \mathrm{ka} \\
\left(>5000 \text { particles } \mathrm{cm}^{-3} \text { ) }\right.\end{array}$ & $\begin{array}{l}\text { Expansion } \\
\text { of oak } \\
\text { steppe- } \\
\text { forest } \\
\text { along with } \\
\text { Mediter- } \\
\text { ranean } \\
\text { taxa } \\
\text { (Pistacia), } \\
\text { short-term } \\
\text { influence } \\
\text { of steppe } \\
\text { vegetation }\end{array}$ & $7 \mathrm{a}$ \\
\hline & 2 & $\begin{array}{l}99.88- \\
101.30\end{array}$ & $\begin{array}{l}203.11- \\
207.56\end{array}$ & $\begin{array}{l}\mathrm{AP}<40 \% \\
\text { decrease Quer- } \\
\text { cus }\end{array}$ & $\begin{array}{l}\text { Reduced AP values }(17-50 \%) \text {, mainly by } \\
\text { dec. Quercus }(10-30 \%) \text { and Pinus (1- } \\
8 \%) \text { but still above } 15 \% \text {; increase in } \\
\text { Ephedra distachya-type (1-3\%) and Be- } \\
\text { tula }(0-2 \%) \\
\text { NAP: expansion of Chenopodiaceae (15- } \\
47 \%) \text {, peak of Artemisia (9-32\%) at the } \\
\text { beginning; moderate Poaceae }(5-19 \%) \\
\text { GA low, DC low to high, CC low to mod- } \\
\text { erate }\end{array}$ & $\begin{array}{l}\text { More open } \\
\text { (steppe) } \\
\text { landscape } \\
\text { with still } \\
\text { patchy pi- } \\
\text { oneer and } \\
\text { temperate } \\
\text { trees }\end{array}$ & $7 b$ \\
\hline & 3 & $\begin{array}{l}101.30- \\
104.19\end{array}$ & $\begin{array}{l}207.56- \\
216.28\end{array}$ & $\begin{array}{l}\text { Chenopodiaceae } \\
<40 \% \text {; increase } \\
\text { Quercus }\end{array}$ & $\begin{array}{l}\text { AP: Predominance of dec. Quercus }(2- \\
56 \%) \text { with significant peak at } 102.8 \text { mcblf } \\
(212.6 \mathrm{ka}) \text { followed by a decreasing trend; } \\
\text { high values of Pinus }(0-19 \%) \text {; Betula } \\
(0-4 \%) \text { and Juniperus }(0-2 \%) \text { are } \\
\text { abundant; Pistacia cf. atlantica and } \\
\text { Ulmus pollen occur sporadically; high } \\
\left.\text { AP concentration ( }>3000 \text { grains } \mathrm{cm}^{-3}\right) \\
\text { NAP: peak of Artemisia }(6-38 \%) \text {, } \\
\text { Poaceae (5-21\%), and Tubuliflorae } \\
(2-13 \%) \text { at the beginning; very low } \\
\text { Chenopodiaceae values }(4-48 \%) \\
\text { GA low, DC no occurrence, CC high }\end{array}$ & $\begin{array}{l}\text { Expansion } \\
\text { of } \\
\text { oak-pine } \\
\text { steppe- } \\
\text { forest }\end{array}$ & $7 \mathrm{c}$ \\
\hline
\end{tabular}


Table 2. Continued.

\begin{tabular}{|c|c|c|c|c|c|c|c|}
\hline PAS & PAZ & $\begin{array}{l}\text { Composite } \\
\text { depth } \\
\text { (mcblf) }\end{array}$ & $\begin{array}{l}\text { Age } \\
\text { (ka) }\end{array}$ & $\begin{array}{l}\text { Criteria for } \\
\text { lower boundary }\end{array}$ & $\begin{array}{l}\text { Main palynological characteristics } \\
\text { (minimum to maximum in } \% \text { ) }\end{array}$ & $\begin{array}{l}\text { Dominant } \\
\text { vegetation } \\
\text { type }\end{array}$ & MIS \\
\hline $\mathrm{Vb}$ & & $\begin{array}{l}104.19- \\
109.05\end{array}$ & $\begin{array}{l}216.28- \\
227.42\end{array}$ & $\begin{array}{l}\text { Chenopodiaceae } \\
>40 \%\end{array}$ & $\begin{array}{l}\text { Very low AP percentages }(1-12 \%) \text { and } \\
\text { concentration }\left(<2000 \text { grains } \mathrm{cm}^{-3}\right) \text {; } \\
\text { decrease in dec. Quercus }(0-9 \%), P i- \\
\text { nus }(0-3 \%) \text {, and Juniperus }(<1 \%) \\
\text { NAP: Predominance of Chenopodi- } \\
\text { aceae }(37-76 \%) \text {; Poaceae }(4-15 \%) \text {, } \\
\text { and Artemisia }(6-26 \%) \text { are abundant } \\
\text { GA low, DC low, CC low with moder- } \\
\text { ate values at the end }\end{array}$ & $\begin{array}{l}\text { Extensive } \\
\text { desert- } \\
\text { steppe } \\
\text { vegetation }\end{array}$ & $7 d$ \\
\hline \multirow[t]{6}{*}{$\mathrm{Vc}$} & 1 & $\begin{array}{l}109.05- \\
109.94\end{array}$ & $\begin{array}{l}227.42- \\
230.71\end{array}$ & $\begin{array}{l}\text { Disappearance } \\
\text { Pistacia; de- } \\
\text { crease AP; } \\
\text { increase } \\
\text { Chenopodi- } \\
\text { aceae }\end{array}$ & $\begin{array}{l}\text { Decrease in AP (14-19\%), mainly } \\
\text { dec. Quercus (2-5\%), Pinus (2-10\%); } \\
\text { Pistacia cf. atlantica disappears } \\
\text { NAP: Strong increase in Chenopodi- } \\
\text { aceae }(23-32 \%) \text {, reduced Artemisia } \\
\text { (19-27\%) and Poaceae (18-26\%) } \\
\text { GA low, DC low, CC low }\end{array}$ & $\begin{array}{l}\text { Increasing } \\
\text { influence } \\
\text { of steppe } \\
\text { taxa, ex- } \\
\text { pansion of } \\
\text { open } \\
\text { vegetation }\end{array}$ & $7 \mathrm{e}$ \\
\hline & 2 & $\begin{array}{l}109.94- \\
111.73\end{array}$ & $\begin{array}{l}230.71- \\
236.95\end{array}$ & $\begin{array}{l}\text { Decrease Quer- } \\
\text { cus and Pista- } \\
\text { cia; } \\
\text { increase Pinus }\end{array}$ & $\begin{array}{l}\text { AP: percentages of dec. Quercus (6- } \\
21 \%) \text {, Betula (0-1\% and Pistacia cf. } \\
\text { atlantica decline while those of Pinus } \\
(4-26 \%) \text { and Juniperus }(2-5 \%) \text { rise } \\
\text { NAP: Increased steppic taxa, e.g., } \\
\text { Artemisia (5-26\%) and Poaceae ( } 21- \\
36 \%) \text {; still low Chenopodiaceae (3- } \\
13 \%) \\
\text { GA high, DC low, CC low with one } \\
\text { peak at the end }\end{array}$ & $\begin{array}{l}\text { All tem- } \\
\text { perate } \\
\text { tree taxa } \\
\text { declined } \\
\text { gradually, } \\
\text { while } \\
\text { Pinus and } \\
\text { grassland } \\
\text { expanded } \\
\text { (Pinus- } \\
\text { dominated } \\
\text { steppe- } \\
\text { forest) }\end{array}$ & \\
\hline & 3 & $\begin{array}{l}111.73- \\
112.64\end{array}$ & $\begin{array}{l}236.95- \\
240.31\end{array}$ & $\begin{array}{l}\text { Quercus > } 10 \% \text {; } \\
\text { Chenopodiaceae } \\
<40 \%\end{array}$ & $\begin{array}{l}\text { AP: peak values for Betula }(4-8 \%) \text { and } \\
\text { Pistacia cf. atlantica }(1-2 \%) \text {, expan- } \\
\text { sion of dec. Quercus }(10-40 \%) \text {; Pinus } \\
(0-3 \%) \text {, Juniperus }(0-1 \%) \text {, and Ulmus } \\
\text { are abundant; highest AP concentration } \\
\left.\text { (ca. 5300-15300 grains cm }{ }^{-3}\right) \\
\text { NAP: retreat in steppe percentages, } \\
\text { mainly Artemisia }(13-37 \%) \text { Chenopo- } \\
\text { diaceae (3-6\%); moderate Poaceae } \\
\text { values (12-20\%) } \\
\text { GA low, DC no occurrence, CC mod- } \\
\text { erate to high }\end{array}$ & $\begin{array}{l}\text { Expansion } \\
\text { of oak } \\
\text { steppe- } \\
\text { forest } \\
\text { along with } \\
\text { Mediter- } \\
\text { ranean } \\
\text { sclero- } \\
\text { phylls } \\
\text { (Pistacia) }\end{array}$ & \\
\hline & 4 & $\begin{array}{l}112.64- \\
113.70\end{array}$ & $\begin{array}{l}240.31- \\
242.48\end{array}$ & $\begin{array}{l}\text { Occurrence } \\
\text { Pistacia }\end{array}$ & $\begin{array}{l}\text { Increase in temperate AP, e.g., dec. } \\
\text { Quercus }(1-10 \%) \text { and Betula }(1-5 \%) \text {; } \\
\text { occurrence of Pistacia cf. atlantica } \\
(\sim 1 \%) \text {, Juniperus }(\sim 1 \%) \text {, and Ulmus } \\
\text { (sporadic) }\end{array}$ & $\begin{array}{l}\text { Steppe } \\
\text { taxa be- } \\
\text { come less } \\
\text { widespread, } \\
\text { giving way }\end{array}$ & \\
\hline & & & & & $\begin{array}{l}\text { NAP: Herbaceous taxa continue, } \\
\text { mainly Poaceae }(7-20 \%) \text { and } \\
\text { Artemisia } \quad(37-56 \%) ; \quad \text { Chenopodi- } \\
\text { aceae decrease }(6-59 \%)\end{array}$ & $\begin{array}{l}\text { to open } \\
\text { grassland }\end{array}$ & \\
\hline & & & & & $\begin{array}{l}\text { GA low, DC no occurrence, CC } \\
\text { moderate to high }\end{array}$ & & \\
\hline
\end{tabular}


Table 2. Continued.

\begin{tabular}{|c|c|c|c|c|c|c|c|}
\hline PAS & PAZ & $\begin{array}{l}\text { Composite } \\
\text { depth } \\
\text { (mcblf) }\end{array}$ & $\begin{array}{l}\text { Age } \\
(\mathrm{ka})\end{array}$ & $\begin{array}{l}\text { Criteria for } \\
\text { lower boundary }\end{array}$ & $\begin{array}{l}\text { Main palynological characteristics } \\
\text { (minimum to maximum in } \% \text { ) }\end{array}$ & $\begin{array}{l}\text { Dominant } \\
\text { vegetation } \\
\text { type }\end{array}$ & MIS \\
\hline VI & & $\begin{array}{l}113.70- \\
117.19\end{array}$ & $\begin{array}{l}242.48- \\
250.16\end{array}$ & Not defined & $\begin{array}{l}\text { Very low abundances of AP (Betula } \\
0-1 \% \text { and dec. Quercus } 0-1 \% \text { ), very } \\
\text { low tree concentration (ca. } 570-1320 \\
\text { grains } \mathrm{cm}^{-3} \text { ) } \\
\text { NAP: Predominance of steppe taxa, } \\
\text { mainly Chenopodiaceae }(52-66 \%) \\
\text { and Artemisia }(18-33 \%) \\
\text { GA low, DC low, CC moderate }\end{array}$ & $\begin{array}{l}\text { Extensive } \\
\text { open } \\
\text { desert- } \\
\text { steppe } \\
\text { vegetation }\end{array}$ & 8 \\
\hline
\end{tabular}

$30 \%$. These phases are predominantly represented by deciduous Quercus (max. $\sim 56 \%$ ), Pinus (max. $\sim 26 \%$ ), Betula (max. $\sim 8 \%$ ), and Juniperus (max. $\sim 7 \%$ ). However, AP maxima do not exceed 60-70\%, suggesting that "closed" forest conditions were never established in eastern Anatolia. Mediterranean sclerophylls, e.g., Pistacia cf. atlantica, are only present sporadically and at very low percentages. During open non-forested periods, the most significant herbaceous taxa are the steppe elements Chenopodiaceae (max. $\sim 76 \%$ ), Artemisia (max. $\sim 56 \%$ ), and further herbs, such as Poaceae (max. $\sim 54 \%$ ), Tubuliflorae (max. $\sim 13 \%$ ), and Liguliflorae (max. $\sim 10 \%$ ).

Throughout the sequence, the total pollen concentration values vary between ca. 1700 and 52000 grains $\mathrm{cm}^{-3}$. During PAZ IV1-6, Va2, Vb, and VI, the pollen concentration is dominated mainly by steppic herbaceous pollen species (between 5000 and 52000 grains $\mathrm{cm}^{-3}$ ), whereas PAZ IIIc6, $\mathrm{Va} 1, \mathrm{Va} 3$, and $\mathrm{Vc} 2-3$ consist of tree and shrub taxa (all above ca. 5000 grains $\mathrm{cm}^{-3}$ ).

In total, six green algae taxa were identified in the Lake Van sediments. Figure $2 \mathrm{a}$ presents only the most important Pseudopediastrum species. The density of the thermophilic taxa Pseudopediastrum boryanum reached maximum values (ca. 5500 coenobia $\mathrm{cm}^{-3}$ ) combined with high AP percentages especially during PAZ Vc2. In contrast, the cold-tolerant species Pseudopediastrum kawraiskyi occurred during treeless phases (PAZ IV4-2; max. values ca. 2000 coenobia $\mathrm{cm}^{-3}$ ).

Furthermore, we calculated the dinoflagellate concentration (probably Spiniferites bentorii; cysts $\mathrm{cm}^{-3}$ ) in order to get additional information about the environmental conditions of the lake water (Dale, 2001; Shumilovskikh et al., 2012). The occurrence of Spiniferites spp. in lacustrine sediments suggests low aquatic bioproductivity (low nutrient level) and hypersaline conditions (Zonneveld and Pospelova, 2015; Zonneveld et al., 2013). In this study, the concentration of dinoflagellate cysts is high (500-2000 cysts $\mathrm{cm}^{-3}$ ) during non-forested periods, especially within PAZ IV1, IV3, IV5, Va2, and PAS Vb (Fig. 2a).
The microscopic charcoal concentrations range between 300 and $\sim 3000$ particles $\mathrm{cm}^{-3}$ during non-forested phases when terrestrial biomass was relatively low (PAZ IV15, Va2, Vb, and Vc1; Fig. 2a). During forested phases, the charcoal content reaches maximum values of ca. 8000 particles $\mathrm{cm}^{-3}$ (e.g., in PAZ Va3 and Vc4-2).

\subsection{The oxygen isotopic composition of Lake Van sediments}

The general pattern of the Lake Van isotope composition of bulk sediments shows very high-frequency oscillation (Fig. 3). The $\delta^{18} \mathrm{O}_{\text {bulk }}$ ranges from ca. 5.9 to $-4.6 \%$ o. Positive values occur between 250 and $244 \mathrm{ka}, 238$ and $222 \mathrm{ka}$, at $215 \mathrm{ka}$, between 213 and $203 \mathrm{ka}, 192$ and $190 \mathrm{ka}, 189$ and $182 \mathrm{ka}$, and mainly between 171 and $157 \mathrm{ka}$ and between 141 and $134 \mathrm{ka}$. Negative isotope composition $\left(\delta^{18} \mathrm{O}_{\text {bulk }}\right.$ below $0 \%$ o) can be observed at $\sim 241 \mathrm{ka}$, between 221 and $216 \mathrm{ka}$, 202 and $194 \mathrm{ka}$, at $\sim 181 \mathrm{ka}$, between 178 and $171 \mathrm{ka}$, and between 156 and $155 \mathrm{ka}$.

Previous studies at Lake Van (e.g., Kwiecien et al., 2014; Lemcke and Sturm, 1997; Litt et al., 2012, 2009; Wick et al., 2003) have shown that the stable isotope signature of lake carbonates reflects the complex interaction between both regional climatic variables and local site-specific factors. Such climate variables are the moisture source, in this case the eastern Mediterranean Sea surface water and the storm trajectories coming from the Mediterranean Sea, as well as temperature changes. Furthermore, the lake water itself is related to the seasonality of precipitation (both rainfall and snowfall; water inflow) and evaporation processes in the catchment area. However, the Lake Van authigenic carbonate $\delta^{18} \mathrm{O}_{\text {bulk }}$ values are primarily controlled by water temperature and the isotopic composition of the lake water $\left(T+\delta^{18} \mathrm{O}_{\mathrm{w}}\right.$; Kwiecien et al., 2014; Leng and Marshall, 2004; Roberts et al., 2008).

At the beginning of terrestrial temperate intervals (e.g., PAZ Vc4, the end of $\mathrm{Vb}$, Va1, and IIIc6), the $\delta^{18} \mathrm{O}_{\text {bulk }}$ composition of the lake water becomes more depleted (Fig. 3c). According to Kwiecien et al. (2014) and Roberts et al. (2008), negative isotope values at the beginning of tem- 


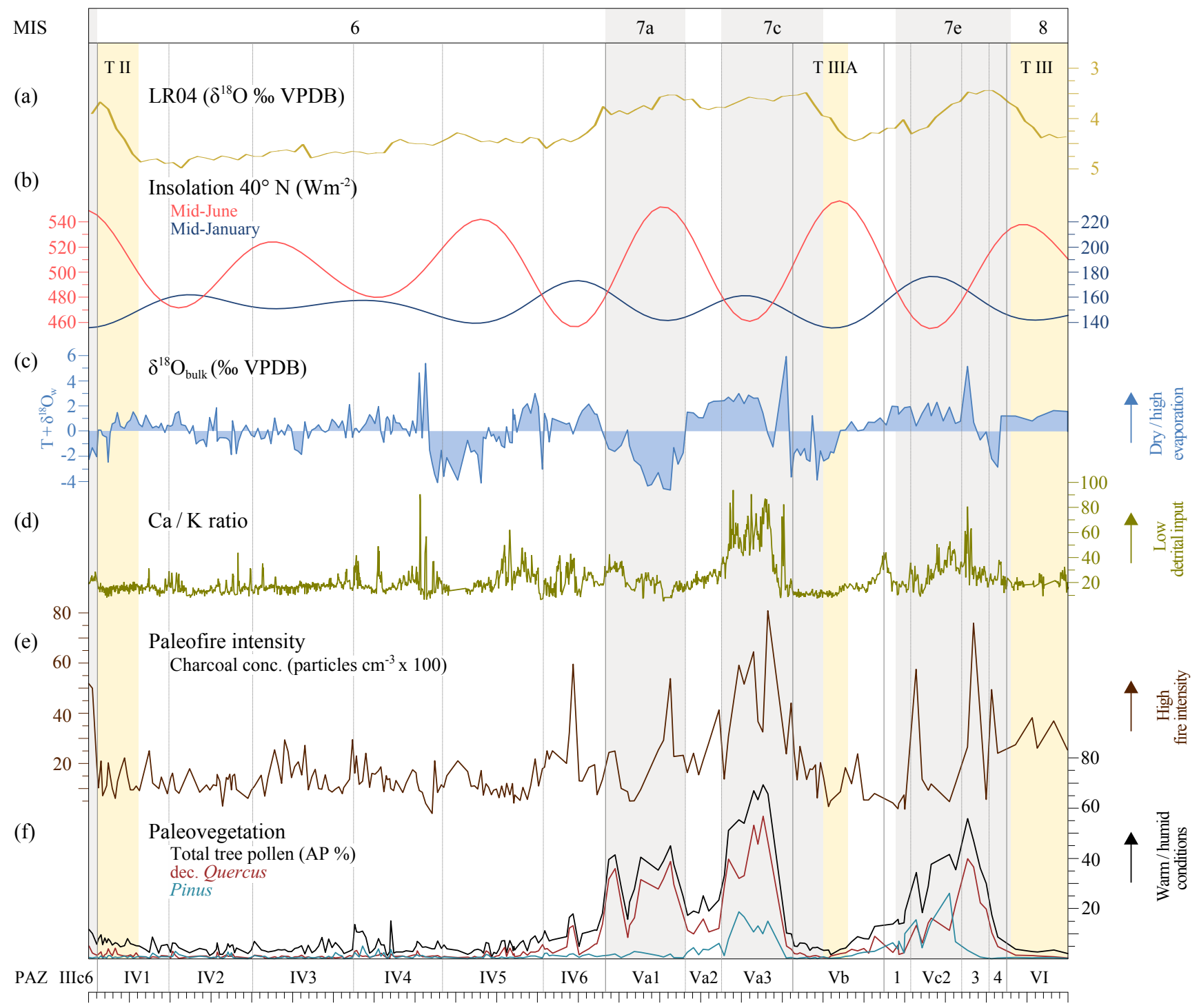

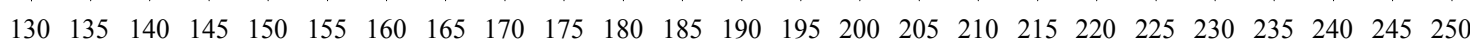

Age (ka)

Figure 3. Comparative study of Lake Van paleoenvironmental proxies during the penultimate interglacial-glacial cycle. (a) LR04 isotopic record (in \%o VPDB) with marine isotope stage (MIS) boundaries (gray bars) following Lisiecki and Raymo (2004). (b) Insolation values $\left(40^{\circ} \mathrm{N}, \mathrm{Wm}^{-2}\right)$ after Berger (1978) and Berger et al. (2007). (c) Lake Van oxygen isotope record $\delta^{18} \mathrm{O}_{\text {bulk }}(\%$ o VPDB; newly analyzed isotope data including the already published isotope record by Kwiecien et al., 2014). (d) Calcium/potassium ratio (Ca / K) after Kwiecien et al. (2014). (e) Fire intensity at Lake Van $\left(>20 \mu \mathrm{m}\right.$; charcoal concentration in particles $\left.\mathrm{cm}^{-3}\right)$. (f) Selected tree percentages (total arboreal pollen (AP), deciduous Quercus, and Pinus) including the pollen data from Litt et al. (2014); PAZ is pollen assemblage zone. Termination III at $250 \mathrm{ka}$, TIIIA at $223 \mathrm{ka}$, and TII at $136 \mathrm{ka}$ are indicated after Barker et al. (2011) and Stockhecke et al. (2014a).

perate intervals document not only enhanced precipitation during winter months, but also the significant contribution of depleted snowmelt and/or glacier meltwater during the summer months.

\section{Discussion}

\subsection{Boundary definition and biostratigraphy}

Based on long continental records in southern Europe (compiled by Tzedakis et al., 1997, 2001) and in the eastern Mediterranean area (Litt et al., 2014; Stockhecke et al., 2014a), it was shown that there is a broad correspondence between warm climatic intervals, especially periods of low 
ice volume as defined by the marine isotope stage (MIS; Lisiecki and Raymo, 2004), and terrestrial temperate intervals (forested periods). In the continental semiarid Lake Van area, it is difficult to use only the expansion of trees as a criterion for the lower boundary of a warm stage. Therefore, the climatic boundaries at Lake Van were mainly defined by abiotic proxies (i.e., TOC) caused by a higher time resolution (Stockhecke et al., 2014a). However, we are aware that using different proxies does not necessarily result in the same dates on the timescale (Sánchez Goñi et al., 1999; Shackleton et al., 2003). Even though we present a high-resolution pollen record in this paper, leads and lags between different biotic and abiotic proxies related to climate events have to be taken into account.

In addition, glacial to interglacial transitions (terminations) are globally near-synchronous and abrupt climate changes. This scenario includes the rising of the Northern Hemisphere summer insolation, leading to ice sheet melting and freshwater supply into the Atlantic Ocean (Denton et al., 2010). In this study, we follow the structure of TIII at $250 \mathrm{ka}$, TIIIA at $223 \mathrm{ka}$, and TII at $136 \mathrm{ka}$ after Barker et al. (2011) and Stockhecke et al. (2014a; Figs. 3, 5).

The climatostratigraphical terms "interglacial" and "interstadial" were originally defined by Jessen and Milthers (1928) on the basis of paleobotanical criteria that are still generally accepted. Here, an interglacial is understood as a temperate period with a climatic optimum at least as warm as the present-day interglacial (Holocene) climate in the same region. An interstadial is defined as a warm period that was either too short or too cold to reach the climate level of an interglacial in the same region. This definition is also valid for the Lake Van region as shown by Litt et al. (2014). In comparison, stadial stages correspond to cold and dry intervals marked by global and local ice re-advances (Lowe and Walker, 1984).

\subsection{The penultimate interglacial complex (MIS 7)}

According to Litt et al. (2014), the three marked temperate arboreal pollen peaks (PAS Vc, Va3, and Va1) can be described as an interglacial complex. This general pattern of triplicate warm phases interrupted by two terrestrial cold periods (PAS Vb, PAZ Va2) is characteristic in both marine and ice core records (MIS 7e, 7c, and 7a after Lisiecki and Raymo, 2004) as well as for the continental pollen sequences in southern Europe correlated and synchronized by Tzedakis et al. (2001).

\subsubsection{Forested periods}

Within the penultimate interglacial complex, the three pronounced steppe-forested intervals PAS Vc (113.7109.1 mcblf; 242.5-227.4 ka), PAZ Va3 (104.2-101.3 mcblf; 216.3-207.6 ka), and PAZ Va1 (99.9-97.0 mcblf; 203.1$193.4 \mathrm{ka}$ ) can be broadly correlated with MIS 7e, 7c, and MIS 7a after Lisiecki and Raymo (2004), indicating high moisture availability and/or warmer temperatures (Figs. 2a, 3f).

The oldest terrestrial warm phase $(242.5-227.4 \mathrm{ka}$; PAS Vc, MIS 7e) starts with the colonization of open habitats by pioneer trees, such as Betula, followed by deciduous Quercus and sclerophyllous Pistacia cf. atlantica. The occurrence of the frost-sensitive Pistacia, as a characteristic feature at the beginning of interglacials in the eastern Mediterranean region, indicates relatively mild winters, but also firmly points to the presence of summer aridity due to a higher temperature and evaporation regime (Litt et al., 2014, 2009; Pickarski et al., 2015a; Wick et al., 2003). Similar to the Holocene, the early interglacial spring and summer dryness might be responsible for the delay between the onset of climatic amelioration and the establishment of deciduous oak steppe-forest as the potential natural interglacial vegetation in eastern Anatolia. Here, the length of the delay depends on local conditions in keeping moisture availability below the tolerance threshold for tree growth in the more ecologically stressed areas. Indeed, a reduction in spring rainfall and the extension of summer-dry conditions favored the rapid development of a grass-dominated landscape (mainly Artemisia, Poaceae; Fig. 2b). Furthermore, the fire activity rose at the beginning of each warm phase when the global temperature increased and the vegetation communities changed from warm productive grasslands to more steppe-forested environments. Increased fire frequency is clearly visualized by a high charcoal concentration of up to 3000 particles $\mathrm{cm}^{-3}$ (Fig. 3e). After TIII at $243 \mathrm{ka}$, the vegetation change towards more steppe-forest environments correlates with depleted (negative) $\delta^{18} \mathrm{O}_{\text {bulk }}$ values, which occur at the beginning of the early temperate stage (ca. 242-240 ka; Fig. 3c). As discussed earlier, depleted isotope values reflect intensified freshwater supply into the lake by melting Bitlis glaciers in summer months, favoring high detrital input into the basin (low $\mathrm{Ca} / \mathrm{K}$ ratio; Fig. 3d) and/or enhanced precipitation during winter months (Kwiecien et al., 2014; Roberts et al., 2008).

The climate optimum of the first warm phase is characterized by the significant expansion of temperate summergreen taxa, mainly deciduous Quercus (above $20 \%$ between ca. 240 and $237 \mathrm{ka}$ ), Pistacia cf. atlantica, Betula, and sporadic occurrence of Ulmus. The vegetation composition documents a warm temperate environment with enhanced precipitation during the growing season, which can be supported by depleted isotope values $\left(\delta^{18} \mathrm{O}_{\text {bulk }}-2.17 \%\right.$; Fig. 3c). Charcoal maxima $\left(>3000\right.$ particles $\mathrm{cm}^{-3}$ ) correlate, coeval with the delayed expansion of steppe-forest, with more fuel for burning. The gradual shift from depleted to enriched isotope values $\left(\delta^{18} \mathrm{O}_{\text {bulk }} 5.15 \%\right)$ indicates a change towards climate conditions with high evaporation rates and/or decreased moisture availability (Kwiecien et al., 2014; Roberts et al., 2008). Here, positive $\delta^{18} \mathrm{O}_{\text {bulk }}$ values at Lake Van are attributed to the evaporative ${ }^{18} \mathrm{O}$ enrichment of the lake water during the dry season. Furthermore, Kwiecien et al. (2014) described the relation between soil erosion processes and 
vegetation cover in the catchment area. They defined interglacial conditions related to increased precipitation indicated by a higher amount of arboreal pollen and lower detrital input. Our new high-resolution pollen record validates their hypothesis with a high authigenic carbonate concentration (high $\mathrm{Ca} / \mathrm{K}$ ratio, low terrestrial input) along with increased terrestrial vegetation density (high AP percentages above $50 \%$ ) during the climate optimum (Fig. 3).

The ensuing ecological succession of the first warm stage is documented by a shift from deciduous oak steppeforest towards the predominance of dry-tolerant and/or coldadapted conifer taxa (e.g., Pinus and Juniperus; ca. 237$231 \mathrm{ka}$ ). High percentages of Pinus suggest a cooling and/or drying trend, which occurred during low seasonal contrasts (low summer insolation and high winter insolation; Fig. 3). Pinus (probably Pinus nigra) as a important arboreal component of the "Xero-Euxinian steppe-forest" occurs mainly in more continental western and central Anatolia and in the rain shadow of the coastal Pontic mountain range (van Zeist and Bottema, 1991; Zohary, 1973). Compared to the present distribution of Pinus nigra in Anatolia, the Lake Van region was probably more affected by an extended distribution area of pine during the penultimate interglacial as indicated by higher pollen percentages (Holocene below $5 \%$; PAZ Vc2 up to $26 \%$; PAZ Va3 up to $20 \%$; Fig. 4). Holocene pine pollen was mainly transported over several kilometers via wind into the Lake Van basin. Independent of environmental conditions around the lake, the presence of thermophilic algae (i.e., Pseudopediastrum boryanum) indicates warm and eutrophic conditions within the lake during the late temperate phase.

The presented regional vegetation composition can be described as an oak steppe-forest and marks one of the longest phases of the penultimate interglacial complex, lasting 15000 years, with a climate optimum between 240 and $237 \mathrm{ka}$ (Fig. 4c). However, this optimum does not appear to be of very high intensity as suggested by the lower development of temperate plants compared to the following warm phase.

The second terrestrial temperate interval (end of PAS $\mathrm{Vb}$ and PAZ Va3; 106.5-101.3 mcblf; ca. 221-207 ka; MIS 7c) starts with a shift from cold and arid desert-steppe vegetation (e.g., Chenopodiaceae) to less arid grassland vegetation (e.g., Poaceae, Artemisia; Fig. 2b). This was followed by an expansion of Betula and a high abundance of deciduous Quercus, and it continued with increased Pinus percentages. In this period, the occurrence of Pistacia cf. atlantica was not as pronounced as during the PAS Vc (MIS 7e), which can be explained by a lower winter insolation (cooler winters; Fig. 3b). Despite all this, the oxygen isotope signature displays similarly depleted values $\left(\delta^{18} \mathrm{O}_{\text {bulk }}\right.$ up to $-3.8 \%$; Fig. $\left.3 \mathrm{c}\right)$ at the beginning of the middle warm phase, right after TIIIA at 222 ka (Barker et al., 2011; Stockhecke et al., 2014a). In general, the second warm stage shows the highest amplitude of deciduous Quercus (peaked at 212.6 ka; Fig. 3f) of the entire sequence, which corresponds to the occurrence of the most floristically diverse and complete forest succession in southern European pollen diagrams at the same time (Follieri et al., 1988; Roucoux et al., 2008; Tzedakis et al., 2003b). In fact, deciduous Quercus percentages (ca. 56\%) reach the level of the last interglacial (MIS 5e) and the Holocene forested intervals, representing the most humid and temperate period during the penultimate interglacial complex at Lake Van (Fig. 4; Litt et al., 2014; Pickarski et al., 2015a).

Preliminary comparison with the pollen records of Tenaghi Philippon (Tzedakis et al., 2003b) and the Ioannina basin (Roucoux et al., 2008) suggests that the extent and diversity of vegetation development is clearly controlled by insolation forcing and associated climate regimes (high summer temperatures, high winter precipitation). At Lake Van, the interglacial forest expansion is closely associated with the timing of the mid-June insolation peak (Tzedakis, 2005). In general, Mediterranean sclerophylls and other summerdrought-resistant taxa expand during the period of maximum summer insolation, while thermophilous taxa are better suited to the less seasonal climates of the later part of the interglacial. Indeed, the highest expansion of deciduous Quercus occurs, coeval to Pinus, during the lowest seasonal contrasts (cooler summers and warmer winters). The different amplitudes in the deciduous tree development might have resulted from higher mid-June insolation at the beginning of PAZ Va3 (MIS 7c) relative to PAZ Vc4 (MIS 7e, similar to Holocene levels), despite lower atmospheric $\mathrm{CO}_{2}$ content (ca. 250 ppm, Fig. 5; Jouzel et al., 2007; Lang and Wolff, 2011; Petit et al., 1999; Tzedakis, 2005), thus mirroring the significant variability in regional effective moisture content and/or temperature.

After a short-term climatic deterioration between 207 and $203 \mathrm{ka}$, the spread of Pistacia cf. atlantica and Betula and the predominance of deciduous Quercus characterize the youngest warm phase PAZ Va1 (99.9-97.0 mcblf; 203.1-193.4 ka; MIS 7a) within the penultimate interglacial complex. Similar to the previous warm phases, the deciduous Quercus percentages (ca. 38\%) reach the level of the Holocene forested interval (deciduous Quercus ca. 40\%; Fig. 4). A possible explanation for the high thermophilous oak percentages within MIS 7a is the persistence of relatively large tree populations through the cold period equivalent to MIS 7b, which was also established in pollen records by Lac du Bouchet (Reille et al., 2000) and at the Ioannina basin (Roucoux et al., 2008).

All three forested stages of the penultimate interglacial complex are clearly recorded in other long terrestrial pollen sequences from Lebanon and southern Europe: (i) the Yammoûneh record (Gasse et al., 2015), (ii) the Tenaghi Philippon sequence (Tzedakis et al., 2003b), (iii) the Ioannina basin (Roucoux et al., 2008), and (iv) the Lake Ohrid sequence (Sadori et al., 2016). Figure 5 shows that the Lake Van pollen record generally agrees with the vegetation development of the Mediterranean region. However, we have to take into con- 
(a) Current interglacial

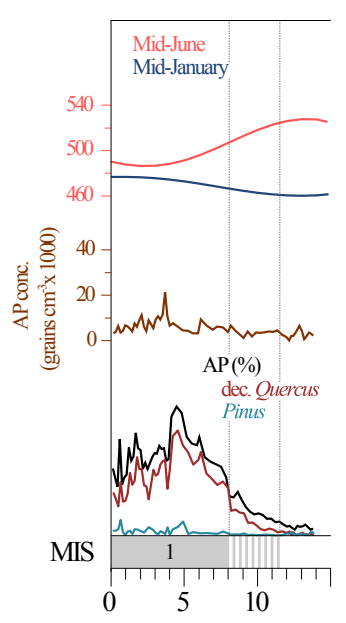

(b) Last interglacial

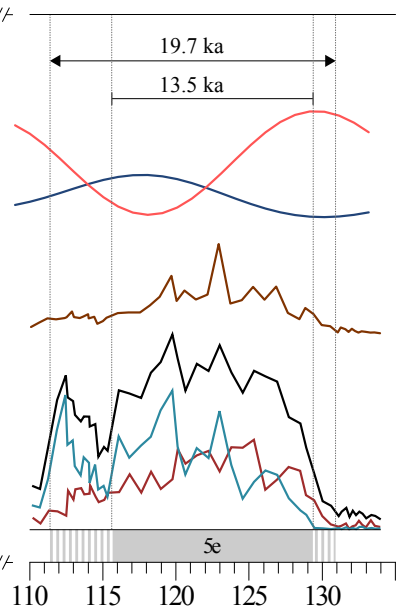

(c) Penultimate interglacial complex

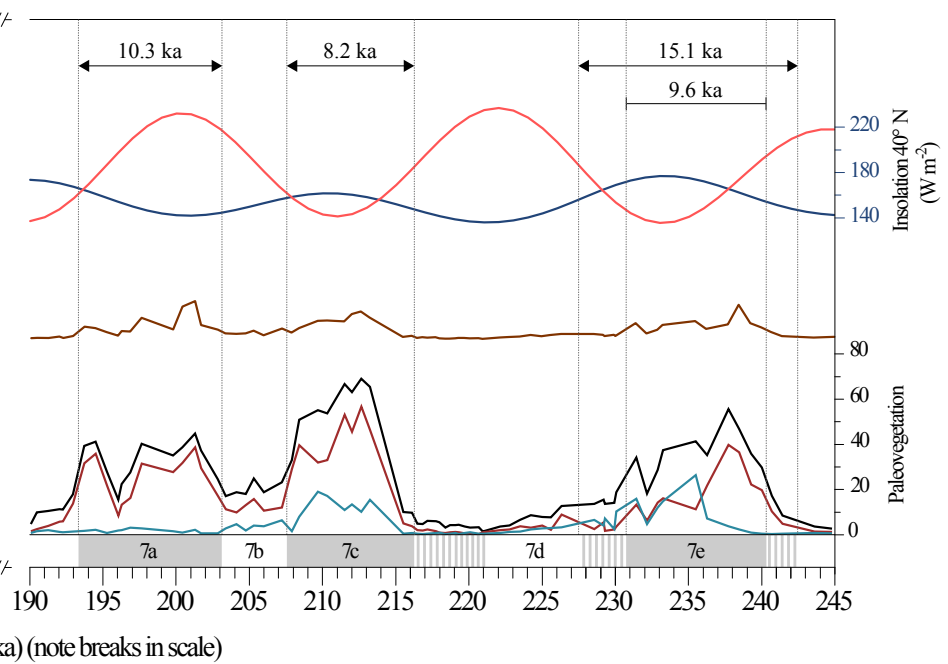

Figure 4. Comparison of (a) current interglacial (MIS 1; Litt et al., 2009) with (b) last interglacial (MIS 5e; Pickarski et al., 2015a) and (c) penultimate interglacial complex (MIS 7; this study) at Lake Van. Shown are the insolation values $\left(40^{\circ} \mathrm{N}\right.$, Wm ${ }^{-2}$ ) after Berger $(1978)$ and Berger et al. (2007), the Lake Van arboreal pollen (AP) concentration (grains $\mathrm{cm}^{-3}$, brown line), and the Lake Van paleovegetation (AP, deciduous Quercus, and Pinus in \%). The gray boxes mark each steppe-forest interval. Marine isotope stage (MIS; Lisiecki and Raymo, 2004) and the length of each interglacial (MIS 5e, 7a, 7c, and 7e; black arrows) are indicated.

sideration that most southern European sequences, e.g., the Ioannina basin, are situated near refugial areas in which temperate trees persisted during cold stages (Bennett et al., 1991; Milner et al., 2013; Roucoux et al., 2008; Tzedakis et al., 2002). In these places where moisture availability was not limiting, the woodland expansion occurred near the glacialinterglacial boundary (Tzedakis, 2007). Despite this, highresolution pollen records from the eastern Mediterranean region (e.g., Ioannina basin; Roucoux et al., 2008) suggest that the MIS 7 winter temperature during all three warm intervals seemed to be lower than during the Holocene and the last interglacial as indicated by smaller populations of sclerophyllous taxa. Reduced thermophilous components were also discussed for the Velay region (Reille et al., 2000), where the warm phases Bouchet 2 and 3, equivalent to MIS 7c and $7 \mathrm{a}$, are described as interstadials rather than interglacials. This observation of a cooler MIS in southern Europe contradicts the vegetation development at Lake Van, where all warm intervals reach the level of the last interglacial and the Holocene. At Lake Van, there seems to be no reason to define MIS 7c and MIS 7a as interstadials separated from the MIS 7e interglacial.

\subsubsection{Non-forested periods}

The two periods between the three forested intervals, the first part of PAZ Vb (227-221 ka; 109.1-106.5 mcblf) and PAS Va2 (208-203 ka; 101.3-99.9 mcblf), are broadly equivalent to MIS 7d and MIS 7a (Lisiecki and Raymo, 2004). At Lake
Van, cold periods are generally characterized by (i) extensive steppe vegetation when tree growth was inhibited either by dry and cold or low atmospheric $\mathrm{CO}_{2}$ conditions (Litt et al., 2014; Pickarski et al., 2015b), (ii) high dinoflagellate concentration (Spiniferites bentorii, which tolerates high water salinity conditions and suggests low aquatic bioproductivity; Fig. 2a), and (iii) high regional mineral input derived from the basin slopes (low Ca / K ratio; Kwiecien et al., 2014; Fig. 3d).

Due to the strongest development of extensive semidesert steppe plants (mainly Chenopodiaceae above $75 \%$ ) and a massive reduction in temperate trees (AP ca. $5 \%$; Fig. 2), the first cold phase suggests considerable climate deterioration and increased aridity. Furthermore, this period is marked by a large ice volume and extremely low global temperatures documented by low $\mathrm{CO}_{2}$ concentrations ( $~ 210$ ppm; Fig. 5) that are nearly as low as those of MIS 8 and 6 (McManus et al., 1999; Petit et al., 1999). Between 227 and $221 \mathrm{ka}$, the oxygen isotope record consistently displays $\delta^{18} \mathrm{O}_{\text {bulk values }}$ above $0 \%$ that reflect dry climate conditions in the Lake Van catchment area (Fig. 3c). Such dry and/or cold periods within the entire penultimate interglacial complex can also be recognized in all pollen sequences from Lebanon and southern Europe (Fig. 5; e.g., Gasse et al., 2015; Roucoux et al., 2008; Tzedakis et al., 2003b). An exception is the Lake Ohrid record, which shows only a minor temperate tree decline (Sadori et al., 2016).

In contrast to conventional cold and dry periods at Lake Van, the second cold phase (PAS Va2) is recognized by 


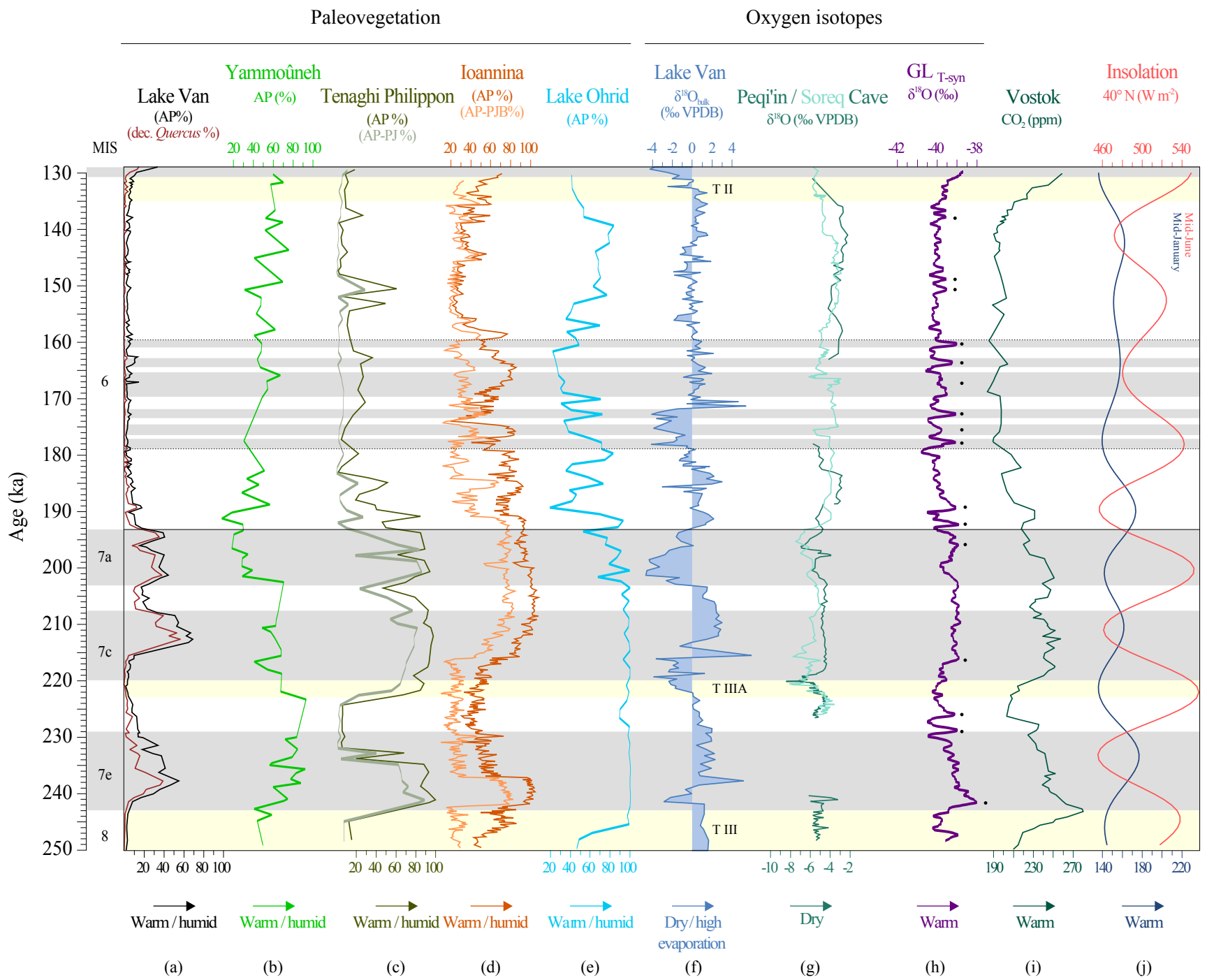

Figure 5. Comparison of Lake Van pollen archive with terrestrial, marine, and ice core paleoclimatic sequences on their own timescales. (a) Total arboreal pollen (AP \%) and deciduous Quercus curve from Lake Van (this study). (b) Arboreal pollen percentages from Yammoûneh basin (Lebanon; Gasse et al., 2015). (c) AP including (green) and excluding (light green) Pinus and Juniperus (PJ) percentages of the Tenaghi Philippon record (NE Greece; Tzedakis et al., 2003b). (d) AP sequence from Ioannina basin including (orange) and excluding (light orange) Pinus, Juniperus, and Betula (PJB; NW Greece; Roucoux et al., 2011, 2008). (e) Lake Ohrid pollen record (AP \%; Macedonia, Albania; Sadori et al., 2016). (f) Stable oxygen isotope record of Lake Van $\left(\delta^{18} \mathrm{O}_{\text {bulk }}\right.$ data including the already published isotope record of Kwiecien et al., 2014). (g) Peqi'in Cave and Soreq Cave speleothem records (Israel; M. Bar-Matthews \& A. Ayalon, unpubl. data). (h) Synthetic Greenland ice core record ( $\mathrm{GL}_{\mathrm{T}-\mathrm{syn}}$; Barker et al., 2011). (i) Atmospheric $\mathrm{CO}_{2}$ concentration from Vostok ice core, Antarctica (Petit et al., 1999). (j) Mid-June and mid-January insolation for $40^{\circ} \mathrm{N}$ (Berger, 1978; Berger et al., 2007). Bands highlight periods of distinctive climate signature discussed in the text. Black dots mark significant interstadial periods. Marine isotope stage is also shown (MIS; Lisiecki and Raymo, 2004). Termination III at $250 \mathrm{ka}$, TIIIA at $223 \mathrm{ka}$, and TII at $136 \mathrm{ka}$ are indicated after Barker et al. (2011) and Stockhecke et al. (2014a).

only a slight and short-term steppe-forest contraction. Although the landscape was more open during the youngest phase, moderate values of Betula, deciduous Quercus (up to $16 \%$ ), and conifers (Pinus, Juniperus) formed steppe vegetation with still patchy pioneer and temperate trees. The significantly larger temperate AP percentages (ca. 20\%) during $\mathrm{PAZ} \mathrm{Va} 2$ relative to $\mathrm{PAZ} \mathrm{Vb}$ point to milder climate conditions. In addition, the continuously heavier oxygen isotope signature ( $\delta^{18} \mathrm{O}_{\text {bulk }}$ between 1.0-2.4\%o) confirms the assumption of milder conditions with higher evaporation rates and more humid conditions. Based on these results, the Lake Van pollen record mirrored the trend seen in various paleoclimatic archives (Fig. 5). Indeed, several pollen sequences from the Mediterranean area and oxygen isotope records sug- 
gest that the North Atlantic and southern European region (e.g., Ioannina basin; Roucoux et al., 2008; Fig. 5d) did not experience severe climatic cooling during MIS 7b (e.g., BarMatthews et al., 2003; Barker et al., 2011; McManus et al., 1999; Petit et al., 1999). In addition, the global ice volume remains relatively low during MIS 7b in comparison with other stadial intervals with similarly low insolation values (e.g., Petit et al., 1999; Shackleton et al., 2000). The Vostok ice core sequence also records a relatively high $\mathrm{CO}_{2}$ content (ca. 230-240 ppm) during MIS 7d, supporting a slight decline in temperature compared with MIS $7 \mathrm{~d}\left(\mathrm{CO}_{2}\right.$ content ca. 207215 ppm; Fig. 5; McManus et al., 1999; Petit et al., 1999).

\subsubsection{Comparison of past interglacials at Lake Van}

The direct comparison of the penultimate interglacial complex (MIS 7) with the last interglacial (Eemian, MIS 5e; Pickarski et al., 2015a) and the current interglacial (Holocene, MIS 1; Litt et al., 2009) provides the opportunity to assess how different successive climate cycles can be (Fig. 4).

In general, all interglacial climate optima were characterized by the development of an oak steppe-forest, all of which reached the level of the last interglacial and the Holocene, especially the extent of the temperate tree taxa. Such dense vegetation cover reduced the physical erosion of the surrounding soils in the lake basin. Furthermore, the dominance of steppe-forested landscapes and a productive steppe environment led to enhanced fire activity in the catchment area. In addition to these aspects, MIS 8-7e and MIS 7d$7 \mathrm{c}$ as well as the MIS 6-5e boundaries in the continental semiarid Lake Van region are recognized by a delayed expansion of deciduous oak steppe-forest of ca. 5000 to 2000 years. This is comparable to the pollen investigations in the marine sediment cores west of Portugal by Sánchez Goñi et al. (2002, 1999). As already shown in high-resolution pollen studies by Wick et al. (2003), Litt et al. (2009), and Pickarski et al. (2015a), a delay in temperate oak steppeforest referring to the Pleistocene-Holocene boundary as defined in the Greenland ice core from NorthGRIP stratotype (for the Pleistocene-Holocene boundary; Walker et al., 2009) as well as from the speleothem-based synthetic Greenland record $\left(\mathrm{GL}_{\mathrm{T}-\mathrm{syn}}\right.$; Barker et al., 2011; Stockhecke et al., 2014a) can be recognized. The length of the delay depends on the slow migration of deciduous trees from arboreal refugia (probably the Caucasus region) and/or changes in the seasonality of effective precipitation rates (ArranzOtaegui et al., 2017; Pickarski et al., 2015a). In particular, oak species are strongly dependent on spring precipitation (El-Moslimany, 1986). A reduction in spring rainfall and the extension of summer-dry conditions favored the rapid development of a grass-dominated landscape (mainly Artemisia, Poaceae; considered as competitors for Quercus seedlings) and Pistacia shrubs in the very sparsely wooded slopes (Asouti and Kabukcu, 2014; Djamali et al., 2010).
Furthermore, the high intensity of wildfires in late summer grasslands at the beginning of each warm period could be responsible for a delayed re-advance of steppe-forest in eastern Anatolia (Arranz-Otaegui et al., 2017; Pickarski et al., 2015a; Turner et al., 2010; Wick et al., 2003).

Despite the common vegetation succession from an early to late temperate stage, the three interglacial periods (MIS 7 complex, MIS 5e, and MIS 1) differ in their vegetation composition. One important difference in the last two interglacial vegetation assemblages is the absence of Carpinus betulus during MIS 7e, 7c, and 7a compared to a distinct Carpinus phase during MIS 5e (Pickarski et al., 2015a). In general, Carpinus betulus usually requires high amounts of annual rainfall (high atmospheric humidity) and a relatively high annual summer temperature, and it is intolerant of late frost (Desprat et al., 2006; Huntley and Birks, 1983). In oak-hornbeam communities, Carpinus betulus is replaced as the soils are relatively dry and warm or too wet (Eaton et al., 2016). Compared to the common hornbeam, deciduous Quercus species are "less" sensitive to summer droughts (even below $60 \mathrm{~mm} \mathrm{yr}^{-1}$; Tzedakis, 2007), and therefore a decrease in soil moisture availability would favor the development of deciduous oaks (Huntley and Birks, 1983). The deep penetrating roots of Quercus petraea allow them to withstand moderate droughts by accessing deeper water (Eaton et al., 2016). However, a variation in temperature is difficult to assess because deciduous oaks at Lake Van include many species (e.g., Quercus brantii, Q. ithaburensis, $Q$. libani, $Q$. robur, $Q$. petraea) with different ecological requirements (e.g., San-Miguel-Ayanz et al., 2016). Finally, the absence of Carpinus betulus, the overall smaller abundances of temperate trees (e.g., Ulmus), and the generally low diversity within the temperate tree populations during the climate optimum of the first penultimate interglacial compared to the last interglacial indicates warm but drier climate conditions (similar to the Holocene). An exception is the second warm phase (MIS 7c), which reflects one of the largest oak steppe-forest developments (e.g., highest amplitude of deciduous Quercus) of the entire Lake Van pollen sequence and thus represents the most humid and temperate period within the penultimate interglacial complex (see discussion above).

Another important difference is the duration of each interglacial period. According to Tzedakis (2005), the beginning and duration of terrestrial temperate intervals in the eastern Mediterranean region is closely linked to the amplitude of summer insolation maxima and less influenced by the timing of deglaciation. Based on this assumption, the terrestrial temperate interval of all penultimate interglacial stages ( $\max$. $15.1 \mathrm{ka})$ is $\sim 4600$ years shorter than the terrestrial temperate interval of the last interglacial at Lake Van $(\sim 19.7 \mathrm{ka}$, Pickarski et al., 2015a; Fig. 4). 


\subsection{The penultimate glacial (MIS 6)}

The following penultimate glacial, PAS IV between 193.4 and 131.2 ka (58.1-96.8 mcblf), can be correlated with MIS 6 (Lisiecki and Raymo, 2004; Figs. 2, 3). Generally lower summer insolation (Berger, 1978; Berger et al., 2007), an increased global ice sheet extent (McManus et al., 1999), and decreasing atmospheric $\mathrm{CO}_{2}$ content (below $230 \mathrm{ppm}$; Petit et al., 1999; Fig. 5) are responsible for enhanced aridity and cooling in eastern Anatolia. Such observed climate deterioration is suggested by the dominance of semidesert plants (e.g., Artemisia, Chenopodiaceae) and by the decline in temperate trees (mainly deciduous Quercus $<5 \%$ ) similar to that of the last glacial at the same site. High erosional activity (low $\mathrm{Ca} / \mathrm{K}$ ratio) and decreasing paleofire $\left(\varnothing \sim 1400\right.$ particles $\left.\mathrm{cm}^{-3}\right)$ result from low vegetation cover with low pollen productivity (Figs. 2, 3). As an additional local factor, the strong deficits in available plant water were possibly stored as ice and glaciers in the Bitlis mountains during the coldest phases.

Between 193 and $157 \mathrm{ka}$, high-frequency vegetation (AP between $\sim 1$ and $18 \%$ ) and environmental oscillations (e.g., $\delta^{18} \mathrm{O}_{\text {bulk }}$ values between -4 to $6 \%$ o in the Lake Van proxies demonstrate a reproducible pattern of centennial- to millennial-scale alternation between interstadials and stadials, as recorded in the Greenland ice core sequences for the last glacial (Fig. 3; e.g., NGRIP, 2004; Rasmussen et al., 2014). Such changes indicate unstable environmental conditions with rapid alternation between slightly warmer and wetter interstadials and cooler and drier stadials at Lake Van. In particular at $189 \mathrm{ka}$, the brief expansion of temperate trees (deciduous Quercus, Betula) and grasses (Poaceae) combined with rapid variations in the fire intensity (up to 6000 particles $\mathrm{cm}^{-3}$; Fig. 3e), the decreasing terrestrial input of soil material (Fig. 3d), and negative $\delta^{18} \mathrm{O}_{\text {bulk values }}$ $(-0.2 \%$ ) points to short-term humid conditions and/or low evaporation within interstadials. Even if mean precipitation was low, the local available moisture was sufficient to sustain arboreal vegetation when low temperature minimized evaporation. Nevertheless, the landscape around the lake was still open due to high percentages of dry-climate-adapted herbs (e.g., Chenopodiaceae).

In contrast, the period after $157 \mathrm{ka}$ shows a greater abundance of steppe elements with dwarf shrubs, grasses, and other herbs (e.g., Chenopodiaceae, Artemisia, Ephedra distachya-type) along with lower temperate tree percentages (AP ca. 1-8\%). The remaining tree populations consist primarily of deciduous Quercus and Pinus, with some scattered patches of Betula and Juniperus. The combination of minor AP percentages, the predominance of steppe plants (Fig. 2b), and reduced fire activity reflect a strong aridification and cold continental climate during the late penultimate glacial. In addition, a general low-amplitude variation in $\delta^{18} \mathrm{O}_{\text {bulk }}$ values (ca. -2 to $2 \%$; Fig. $3 \mathrm{~b}$ ) and overall high local erosion processes (low $\mathrm{Ca} / \mathrm{K}$ ratio; Fig. 3c) refer to a rather stable period with both widespread aridity (low winter and summer precipitation) and low winter temperatures across eastern Anatolia.

The Lake Van record generally agrees with high-frequency paleoenvironmental variations in the ice core archives, highresolution terrestrial European pollen records (e.g., Ioannina basin, Lake Ohrid; Fig. 5), and the marine pollen sequences from the Iberian margin (Margari et al., 2010) in terms of extensive aridity and cooling throughout the penultimate glacial. Our sequence also shares some features with stable isotope speleothem records from western Israel (Peqi' in Cave and Soreq Cave; Ayalon et al., 2002; Bar-Matthews et al., 2003) concerning high $\delta^{18} \mathrm{O}$ values that refer to dry climate conditions. Similar to the Lake Van $\delta^{18} \mathrm{O}_{\text {bulk }}$ values, the Soreq and Peqi' in records also show distinct climate variability, especially at the beginning of MIS 6 (Fig. 5). In addition, several high-resolution terrestrial records document a further period of abrupt warming events between 155 and $150 \mathrm{ka}$. In particular, the Tenaghi Philippon profile illustrates a prominent increase of up to $60 \%$ in arboreal pollen, which coincides with increased rainfall at Yammoûneh (Gasse et al., 2015) and at Peqi' in Cave (Bar-Matthews et al., 2003). At Lake Van, only a weakened short-term oscillation can be detected in the $\mathrm{Ca} / \mathrm{K}$ ratio during that time.

\subsubsection{Comparison of the last two glacial intervals at Lake Van}

The occurrence of high-frequency climate changes within the Lake Van sediments provides an opportunity to compare the vegetation history of the last two glacial periods. Figure 6 illustrates that the first part of the penultimate glacial (ca. 193-157 ka) resembles MIS 3 regarding millennial-scale AP oscillations and the abruptness of the transitions in the pollen record. The series of interstadial-stadial intervals can be recognized in both glacial periods. This variability is mainly influenced by the impact of North Atlantic current oscillations and the extension of atmospheric patterns, in particular the northward shift of the polar front in eastern Anatolia (e.g., Cacho et al., 2000, 1999; Chapman and Shackleton, 1999; McManus et al., 1999; Rasmussen et al., 2014; Wolff et al., 2010).

The most distinct environmental variability occurred during MIS 6e (ca. 179-159 ka), which can be further divided into six interstadials based on rapid changes in the marine core MD01-2444 off Portugal (Margari et al., 2010; Roucoux et al., 2011; Fig. 6). They document abrupt climate oscillations below orbital cycles similar to the Dansgaard-Oeschger (DO) events or Greenland interstadials (GI) over the last glacial stage (e.g., Dansgaard et al., 1993; Rasmussen et al., 2014; Wolff et al., 2010). At Lake Van, MIS 6e reveals clear evidence of climate variability due to rapid alternation in abiotic and biotic proxies, such as oxygen isotopes, $\mathrm{Ca} / \mathrm{K}$ ratio, and pollen data similar to the largest DO 17 to 12 during MIS 3 (ca. 60-44 ka; Pickarski et al., 2015b). Both in- 
(a) Last glacial

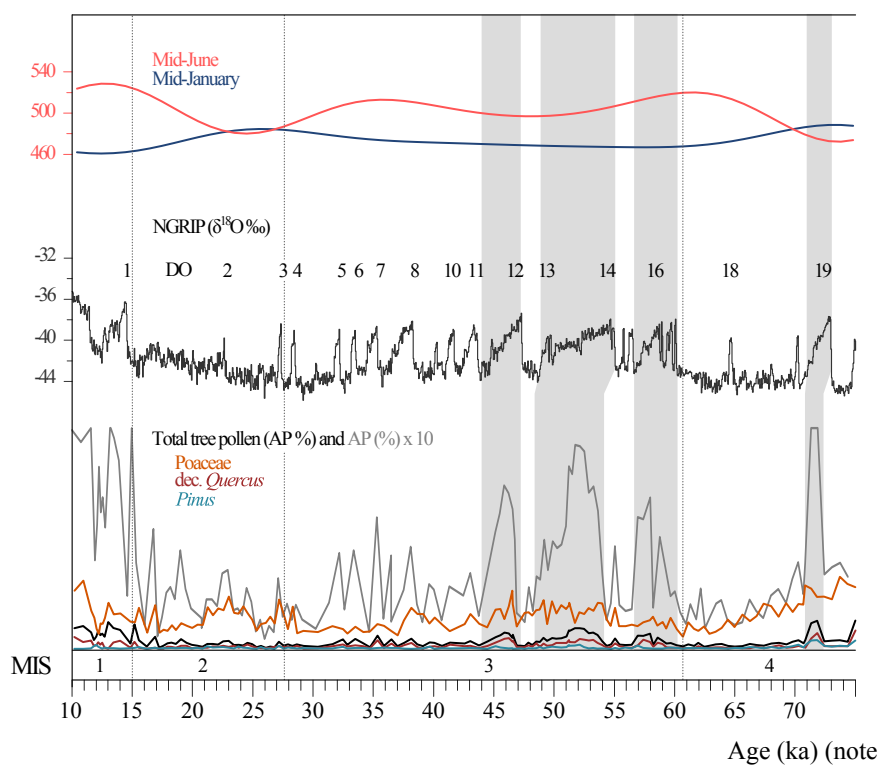

(b) Penultimate glacial

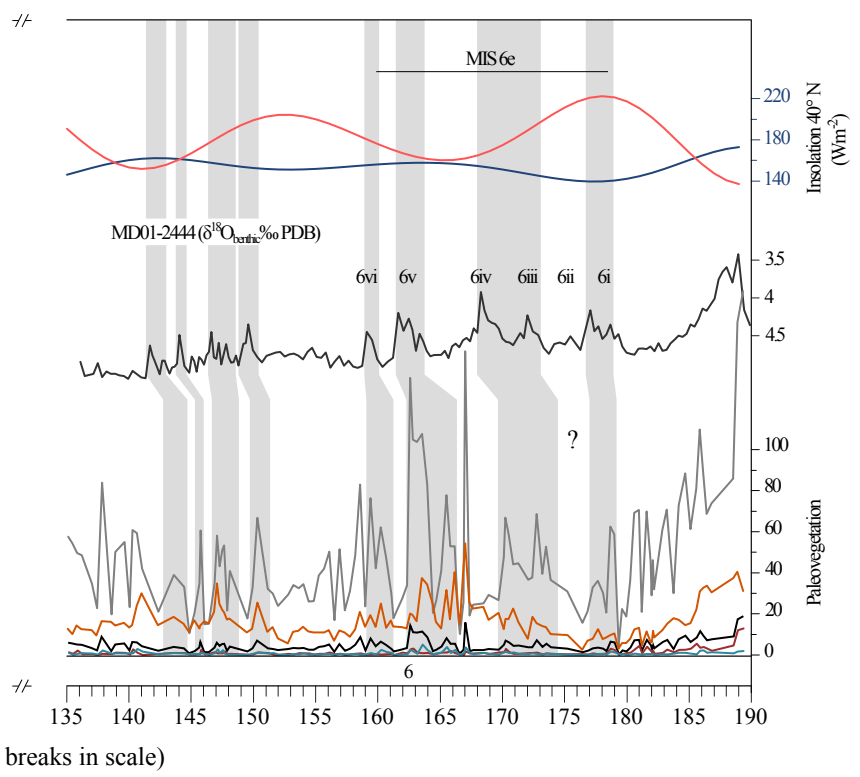

Figure 6. Comparison of the (a) last glacial period (MIS 4-2; Pickarski et al., 2015b) with the (b) penultimate glacial (this study) characteristics at Lake Van. Shown are the insolation values $\left(40^{\circ} \mathrm{N}, \mathrm{Wm}^{-2}\right)$ after Berger (1978) and Berger et al. (2007), the $\delta^{18} \mathrm{O}$ profile from the NGRIP ice core (Greenland; NGRIP members, 2004) labeled with Dansgaard-Oeschger (DO) events 1 to 19 for the last glacial period, the $\delta^{18} \mathrm{O}$ composition of benthic foraminifera of the marine core MD01-2444 (Portuguese margin; Margari et al., 2010) for the penultimate glacial, and the Lake Van paleovegetation with AP \% (shown in black), AP in 10-fold exaggeration (gray line), Poaceae, deciduous Quercus, and Pinus. The gray boxes mark the comparison between the different paleoenvironmental records of pronounced interstadial oscillations. Marine isotope stage (MIS; Lisiecki and Raymo, 2004) and informally numbered interstadials of the MD01-2444 record are indicated (Margari et al., 2010).

tervals, MIS 6e and MIS 3, started at the point of summer insolation maxima. Here, the Northern Hemisphere insolation values reached the interglacial level at the beginning of MIS 6e comparable with MIS 7e (Fig. 5). In contrast, the interstadial-stadial pattern during late MIS 6 oscillated at a lower amplitude similar to the rates of change in the Dansgaard-Oeschger (DO) events during MIS 4 and 2, reflecting a general global climatic cooling.

Within MIS 6e, the subdued temperate tree pollen oscillations consist mainly of deciduous Quercus and Pinus, ranging between $\sim 1$ and $15 \%$. In contrast, the identical AP composition oscillates between $\sim 1$ and $10 \%$ during the orbitally equivalent MIS 3 (ca. 61-28 ka; Pickarski et al., 2015b). The different amplitude in arboreal pollen percentages in both glacial stages and a generally dense temperate grass steppe during MIS 6e suggest more available moisture (Fig. 6). The depleted isotope signature may result from summer meltwater discharge from local glaciers (e.g., Taurus mountains, Bitlis Massif) or increased precipitation identified by climate modeling experiments over the eastern Mediterranean basin (e.g., Stockhecke et al., 2016). However, the presence of Artemisia and Poaceae makes it difficult to disentangle the effects of warming from changes in moisture availability in both glacials. Nevertheless, the abundance of Pinus,
Ephedra distachya-type, and the cold-tolerant algae Pseudopediastrum kawraiskyi indicates colder and wetter climate conditions during MIS 6e compared to MIS 3.

Evidence of relatively humid but cold climate conditions during MIS 6e agrees with several other paleoclimate studies from the Mediterranean area. For example, the occurrence of open forest vegetation associated with a wetter climate is indicated at, e.g., Tenaghi Philippon (Tzedakis et al., 2006, 2003b) and Ioannina (Roucoux et al., 2011). In addition, isotopic evidence of the stalagmite record from Soreq Cave (Israel) shows enhanced rainfall (negative shift in the $\delta^{18} \mathrm{O}$ values) in the eastern Mediterranean at $\sim 177 \mathrm{ka}$ and between 166 and $157 \mathrm{ka}$ (Fig. 5; Ayalon et al., 2002; Bar-Matthews et al., 2003). Furthermore, a pluvial phase is also inferred from a prominent speleothem $\delta^{18} \mathrm{O}$ excursion in Argentarola Cave (Italy) between 180 and $170 \mathrm{ka}$ based on U-Th dating (Bard et al., 2002). This phase coincides with maximum rainfall conditions during the MIS 6.5 event, coeval with the deposition of the "cold" sapropel layer S6 (ca. $\sim 176 \mathrm{ka}$ ) in the western and eastern Mediterranean basin (Ayalon et al., 2002; Bard et al., 2002). Finally, the progressive decline in effective moisture is a result of the combined effect of temperature, precipitation, and insolation changes in the Lake Van region. 


\section{Conclusions}

The new high-resolution Lake Van pollen record provides a unique sequence of the penultimate interglacial-glacial cycle in eastern Anatolia (broadly equivalent to MIS 7 and MIS 6) that fills the gap in data coverage between the northern Levant and southern Europe. It reveals three steppe-forested intervals that can be correlated with MIS 7e, 7c, and 7a. Intervening periods of more open, herbaceous vegetation are correlated with MIS 7d and 7b.

During the penultimate interglacial complex, high local and regional effective soil moisture availability is evidenced by a well-developed temperate oak steppe-forest with pistachio and juniper, high charcoal accumulation, and reduced physical erosion during the climate optima.

In contrast to southwestern Europe, all three terrestrial warm intervals of MIS 7 are characterized by clear interglacial conditions. The largest oak steppe-forest expansion in the Lake Van region within the penultimate interglacial complex occurred during the terrestrial equivalent of MIS 7c instead of MIS 7e. This underlines the different environmental response to global climate change in the continental setting of the Near East compared to global ice volume and/or greenhouse gas.

The eastern Mediterranean Lake Van pollen sequence is in line with data from long-term climate records from southern Europe and the northern Levant in terms of vegetation changes, orbitally induced fluctuations, and atmospheric changes over the North Atlantic system. However, the diversity of tree taxa in the Lake Van pollen spectra seems to be rather low compared to southern European terrestrial interglacials and their forest development.

During the penultimate glacial, strong aridification and cold climate conditions are inferred from open desert-steppe vegetation that favors physical erosion and local terrigenous inputs. In particular, our record reveals high temperate oscillations between 193 and $157 \mathrm{ka}$, followed by a period of lower tree variations and the predominance of desert-steppe from 157 to $131 \mathrm{ka}$ that highlighted Dansgaard-Oeschgerlike events during MIS 6.

Data availability. The complete pollen data set is available online on the PANGAEA database (https://doi.org/10.1594/PANGAEA.871228).

Competing interests. The authors declare that they have no conflict of interest.

Acknowledgements. Financial support was provided by the German Research Foundation (DFG; LI 582/20-1). We thank all colleagues and scientific teams involved in the Lake Van drilling, core opening, and sampling campaigns. We thank Nils Ander- sen and his working team at the Leibnitz Laboratory for the isotopic measurements. We acknowledge Vera Pospelova and Fabienne Marret-Davies for their help in identifying dinoflagellate cysts. We thank Karen Schmeling for preparing excellent pollen samples and Christoph Steinhoff and Helen Böttcher for their support in the lab. Special thanks go to Ola Kwiecien and Georg Heumann for their critical reading of the paper and for the inspiring discussions. Patricia Pawlyk, as a native speaker, is thanked for proofreading the English. We are grateful to Miryam Bar-Matthews and Avner Ayalon from the Geological Survey of Israel (Jerusalem) for supplying the oxygen isotope data of the Soreq and Peqi'in record. We thank the editor, Donatella Magri, Gonzalo Jiménez-Moreno, and the two anonymous reviewers for their constructive comments and useful recommendations, which improved the quality of the paper.

Edited by: Nathalie Combourieu Nebout

Reviewed by: Gonzalo Jiménez-Moreno and two anonymous referees

\section{References}

Altiner, Y., Söhne, W., Güney, C., Perlt, J., Wang, R., and Muzli, M.: A geodetic study of the 23 October 2011 Van, Turkey earthquake, Tectonophysics, 588, 118-134, https://doi.org/10.1016/j.tecto.2012.12.005, 2013.

Arranz-Otaegui, A., López-Sáez, J. A., Araus, J. L., Portillo, M., Balbo, A., Iriarte, E., Gourichon, L., Braemer, F., Zapata, L., and Ibáñez, J. J.: Landscape transformations at the dawn of agriculture in southern Syria (10.7-9.9 ka cal. BP): Plant-specific responses to the impact of human activities and climate change, Quaternary Sci. Rev., 158, 145-163, https://doi.org/10.1016/j.quascirev.2017.01.001, 2017.

Asouti, E. and Kabukcu, C.: Holocene semi-arid oak woodlands in the Irano-Anatolian region of Southwest Asia: natural or anthropogenic?, Quaternary Sci. Rev., 90, 158-182, https://doi.org/10.1016/j.quascirev.2014.03.001, 2014.

Ayalon, A., Bar-Matthews, M., and Kaufman, A.: Climatic conditions during marine oxygen isotope stage 6 in the eastern Mediterranean region from the isotopic composition of speleothems of Soreq Cave, Israel, Geology, 30, 303-306, https://doi.org/10.1130/00917613(2002)030<0303:CCDMOI>2.0.CO;2, 2002.

Bar-Matthews, M., Ayalon, A., Gilmour, M., Matthews, A., and Hawkesworth, C. J.: Sea-land oxygen isotopic relationships from planktonic foraminifera and speleothems in the Eastern Mediterranean region and their implication for paleorainfall during interglacial intervals, Geochim. Cosmochim. Ac., 67, 31813199, https://doi.org/10.1016/S0016-7037(02)01031-1, 2003.

Bard, E., Delaygue, G., Rostek, F., Antonioli, F., Silenzi, S., and Schrag, D. P.: Hydrological conditions over the western Mediterranean basin during the deposition of the cold Sapropel 6 (ca. 175 kyr BP), Earth Planet. Sc. Lett., 202, 481-494, https://doi.org/10.1016/S0012-821X(02)00788-4, 2002.

Barker, S., Knorr, G., Edwards, R.L., Parrenin, F., Putnam, A.E., Skinner, L.C., Wolff, E., and Ziegler, M.: 800,000 Years of Abrupt Climate Variability, Science, 334, 347-351. https://doi.org/10.1126/science.1203580, 2011. 
Bennett, K. D., Tzedakis, P. C., and Willis, K. J.: Quaternary refugia of north European trees, J. Biogeogr., 18, 103-115, https://doi.org/10.2307/2845248, 1991.

Berger, A.: Long-term variations of daily insolation and Quaternary climate changes, J. Atmos. Sci., 35, 2362-2367, https://doi.org/10.1175/15200469(1978)035<2362:LTVODI>2.0.CO;2, 1978.

Berger, A., Loute, M.F., Kaspar, F., and Lorenz, S. J.: Insolation During Interglacial, in: The Climate of Past Interglacial, edited by: Sirocko, F., Claussen, M., Sánchez Goñi, M. F., and Litt, T., Elsevier, Amsterdam, 13-27, 2007.

Berglund, B. E. and Ralska-Jasiewiczowa, M. (Ed.): Pollen anaylsis and pollen diagrams, in: Handbook of Holocene Palaeoecology and Palaeohydrology, John Wiley and Sons, 455-484, 1986.

Beug, H.-J.: Leitfaden der Pollenbestimmung für Mitteleuropa und angrenzende Gebiete, Pfeil, München, 2004.

Cacho, I., Grimalt, J. O., Pelejero, C., Canals, M., Sierro, F. J., Flores, J. A., and Shackleton, N.: Dansgaard-Oeschger and Heinrich event imprints in Alboran Sea paleotemperatures, Paleoceanography, 14, 698-705, https://doi.org/10.1029/1999PA900044, 1999.

Cacho, I., Grimalt, J. O., Sierro, F. J., Shackleton, N. J. S., and Canals, M.: Evidence for enhanced Mediterranean thermohaline circulation during rapid climatic coolings, Earth Planet. Sc. Lett., 183, 417-429, https://doi.org/10.1016/S0012-821X(00)00296X, 2000.

Chapman, M. R. and Shackleton, N. J.: Global ice-volume fluctuations, North Atlantic ice-rafting events, and deepocean circulation changes between 130 and $70 \mathrm{ka}$, Geology, 27, 795-798, https://doi.org/10.1130/00917613(1999)027<0795:GIVFNA>2.3.CO;2, 1999.

Dale, B.: The sedimentary record of dinoflagellate cysts: looking back into the future of phytoplankton blooms, Sci. Mar., 65, 257272, https://doi.org/10.3989/scimar.2001.65s2257, 2001.

Dansgaard, W., Johnsen, S. J., Clausen, H. B., Dahl-Jensen, D., Gundestrup, N. S., Hammer, C. U., Hvidberg, C. S., Steffensen, J.P ., Sveinbjörnsdottir, A. E., Jouzel, J., and Bond, G.: Evidence for general instability of past climate from a $250-\mathrm{kyr}$ ice-core record, Nature, 364, 218-220, 1993.

Denton, G. H., Anderson, R. F., Toggweiler, J. R., Edwards, R. L., Schaefer, J. M., and Putnam, A. E.: The Last Glacial Termination, Science, 328, 1652, https://doi.org/10.1126/science.1184119, 2010.

Desprat, S., Sánchez Goñi, M.F., Turon, J.-L., Duprat, J., Malaizé, B., and Peypouquet, J.-P.: Climatic variability of Marine Isotope Stage 7: direct land-sea-ice correlation from a multiproxy analysis of a north-western Iberian margin deep-sea core, Quaternary Sci. Rev., 25, 1010-1026, https://doi.org/10.1016/j.quascirev.2006.01.001, 2006.

Djamali, M., Akhani, H., Andrieu-Ponel, V., Braconnot, P., Brewer, S., de Beaulieu, J.-L., Fleitmann, D., Fleury, J., Gasse, F., Guibal, F., Jackson, S.T., Lézine, A.-M., Médail, F., Ponel, P., Roberts, N., and Stevens, L.: Indian Summer Monsoon variations could have affected the early-Holocene woodland expansion in the Near East, The Holocene, 20, 813-820, https://doi.org/10.1177/0959683610362813, 2010.

Eaton, E., Caudullo, G., Oliveira, S., and de Rigo, D.: Quercus robur and Quercus petraea in Europe: distribution, habitat, usage and threats, in: European Atlas of Forest Tree Species, edited by: San-Miguel-Ayanz, J., de Rigo, D., Caudullo, G., Houston Durrant, T., and Mauri, A., Publication Office of the European Union, Luxembourg, 160-163, 2016.

El-Moslimany, A.: Ecology and late-Quaternary history of the Kurdo-Zagrosian oak forest near Lake Zeribar, western Iran, Vegetatio, 68, 55-63, https://doi.org/10.1007/BF00031580, 1986.

Faegri, K. and Iversen, J.: Textbook of Pollen Analysis, The Blackburn Press, 1989.

Follieri, M., Magri, D., and Sadori, L.: 250000 -year pollen record from Valle di Castiglione Roma, Pollen et Spores, 30, 329-356, 1988.

Frey, W. and Kürschner, H.: Die Vegetation im Vorderer Orient, Erläuterungen zur Karte A VI 1 Vorderer Orient, Vegetation des “Tübinger Atlas des Vorderen Orients”, Reihe A. Tübinger Atlas des Vorderen Orients, Wiesbaden, 1989.

Frogley, M. R., Tzedakis, P. C., and Heaton, T. H. E.: Climate Variability in Northwest Greece During the Last Interglacial, Science, 285, 1886-1889, https://doi.org/10.1126/science.285.5435.1886, 1999.

Gasse, F., Vidal, L., Develle, A.-L., and Van Campo, E.: Hydrological variability in the Northern Levant: a 250 ka multiproxy record from the Yammoûneh (Lebanon) sedimentary sequence, Clim. Past, 7, 1261-1284, https://doi.org/10.5194/cp-71261-2011, 2011.

Gasse, F., Vidal, L., Van Campo, E., Demory, F., Develle, A.-L., Tachikawa, K., Elias, A., Bard, E., Garcia, M., Sonzogni, C., and Thouveny, N.: Hydroclimatic changes in northern Levant over the past 400000 years, Quaternary Sci. Rev., 111, 1-8, https://doi.org/10.1016/j.quascirev.2014.12.019, 2015.

Giorgi, F. and Lionello, P.: Climate change projections for the Mediterranean region, Global Planet. Change, 63, 90-104, https://doi.org/10.1016/j.gloplacha.2007.09.005, 2008.

Huntley, B. and Birks, H. J. B.: An Atlas of Past and Present Pollen Maps for Europe: 0-13000 BP Yeras Ago, Cambridge University Press, Cambridge, 1983.

Jessen, A. and Milthers, V.: Stratigraphical and paleontological studies of interglacial freshwater deposits in Jutland and Northwest Germany, Danmarks Geologiske Undersøgelse 48, 1-379, 1928.

Jouzel, J., Masson-Delmotte, V., Cattani, O., Dreyfus, G., Falourd, S., Hoffmann, G., Minster, B., Nouet, J., Barnola, J.M., Chappellaz, J., Fischer, H., Gallet, J.C., Johnsen, S., Leuenberger, M., Loulergue, L., Luethi, D., Oerter, H., Parrenin, F., Raisbeck, G., Raynaud, D., Schilt, A., Schwander, J., Selmo, E., Souchez, R., Spahni, R., Stauffer, B., Steffensen, J. P., Stenni, B., Stocker, T. F., Tison, J. L., Werner, M., and Wolff, E. W.: Orbital and Millennial Antarctic Climate Variability over the Past 800000 Years, Science, 317, 793-796, https://doi.org/10.1126/science.1141038, 2007.

Kwiecien, O., Stockhecke, M., Pickarski, N., Heumann, G., Litt, T., Sturm, M., Anselmetti, F., Kipfer, R., and Haug, G. H.: Dynamics of the last four glacial terminations recorded in Lake Van, Turkey, Quaternary Sci. Rev., 104, 42-52, https://doi.org/10.1016/j.quascirev.2014.07.001, 2014.

Lang, N. and Wolff, E. W.: Interglacial and glacial variability from the last $800 \mathrm{ka}$ in marine, ice and terrestrial archives, Clim. Past, 7, 361-380, https://doi.org/10.5194/cp-7-361-2011, 2011. 
Lemcke, G. and Sturm, M.: $\delta^{18} \mathrm{O}$ and trace element measurements as proxy for the reconstruction of climate changes at Lake Van (Turkey): preliminary results, in: Third Millennium BC Climate Change and Old World Collapse, edited by: Dalfes, H. N., Kulka, G., and Weiss, H., NATO ASI Series, 653-679, 1997.

Leng, M. J. and Marshall, J. D.: Palaeoclimate interpretation of stable isotope data from lake sediment archives, Quaternary Sci. Rev., 23, 811-831, https://doi.org/10.1016/j.quascirev.2003.06.012, 2004.

Lisiecki, L. E. and Raymo, M. E.: A Plio-Pleistocene Stack of 57 Globally Distributed Benthic $\delta^{18} \mathrm{O}$ Records, Paleoceanography, 20, 1-16, 2004.

Litt, T. and Anselmetti, F. S.: Lake Van deep drilling project PALEOVAN, Quaternary Sci. Rev., 104, 1-7, https://doi.org/10.1016/j.quascirev.2014.09.026, 2014.

Litt, T., Krastel, S., Sturm, M., Kipfer, R., Örcen, S., Heumann, G., Franz, S. O., Ülgen, U. B., and Niessen, F.: "PALEOVAN", International Continental Scientific Drilling Program (ICDP): site survey results and perspectives, Quaternary Sci. Rev., 28, 15551567, https://doi.org/10.1016/j.quascirev.2009.03.002, 2009.

Litt, T., Anselmetti, F. S., Baumgarten, H., Beer, J., Cagatay, N., Cukur, D., Damci, E., Glombitza, C., Haug, G., Heumann, G., Kallmeyer, H., Kipfer, R., Krastel, S., Kwiecien, O., Meydan, A. F., Orcen, S., Pickarski, N., Randlett, M.-E., Schmincke, H.-U., Schubert, C. J., Sturm, M., Sumita, M., Stockhecke, M., Tomonaga, Y., Vigliotti, L., Wonik, T., and the PALEOVAN Scientific Team: 500000 Years of Environmental History in Eastern Anatolia: The PALEOVAN Drilling Project, Sci. Dril., 14, 18-29, https://doi.org/10.2204/iodp.sd.14.02.2012, 2012.

Litt, T., Pickarski, N., Heumann, G., Stockhecke, M., and Tzedakis, P. C.: A 600000 year long continental pollen record from Lake Van, eastern Anatolia (Turkey), Quaternary Sci. Rev., 104, 3041, https://doi.org/10.1016/j.quascirev.2014.03.017, 2014.

Lowe, J. J. and Walker, M. J. C.: Reconstructing Quaternary Environments, 2nd Edn. Longman, Edinburgh, 1984.

Margari, V., Skinner, L. C., Tzedakis, P. C., Ganopolski, A., Vautravers, M., and Shackleton, N. J.: The nature of millennialscale climate variability during the past two glacial periods, Nat. Geosci., 3, 127-131, https://doi.org/10.1038/ngeo740, 2010.

Martinson, D. G., Pisias, N. G., Hays, J. D., Imbrie, J., Moore Jr., T. C., and Shackleton, N. J.: Age dating and the orbital theory of the ice ages: Development of a high-resolution 0 to 300 000-year chronostratigraphy, Quaternary Res., 27, 1-29, https://doi.org/10.1016/0033-5894(87)90046-9, 1987.

McManus, J. F., Oppo, D. W., and Cullen, J. L.: A 0.5Million-Year Record of Millennial-Scale Climate Variability in the North Atlantic, Science, 283, 971-975, https://doi.org/10.1126/science.283.5404.971, 1999.

Milner, A. M., Müller, U. C., Roucoux, K. H., Collier, R. E. L., Pross, J., Kalaitzidis, S., Christanis, K., and Tzedakis, P. C.: Environmental variability during the Last Interglacial: a new high-resolution pollen record from Tenaghi Philippon, Greece, J. Quaternary Sci., 28, 113-117, https://doi.org/10.1002/jqs.2617, 2013.

Moore, P. D., Webb, J. A., and Collinson, M. E.: Pollen Analysis, Blackwell Science, Oxfort, 216 pp., 1991.

NGRIP: High-resolution record of Northern Hemisphere climate extending into the last interglacial period, Nature, 431, 147-151, https://doi.org/10.1038/nature02805, 2004.
Petit, J. R., Jouzel, J., Raynaud, D., Barkov, N. I., Barnola, J.M., Basile, I., Bender, M., Chappellaz, J., Davis, M., Delaygue, G., Delmotte, M., Kotlyakov, V. M., Legrand, M., Lipenkov, V. Y., Lorius, C., Pepin, L., Ritz, C., Saltzman, E., and Stievenard, M.: Climate and atmospheric history of the past 420,000 years from the Vostok ice core, Antarctica, Nature, 399, 429436, https://doi.org/10.1038/20859, 1999.

Pickarski, N., Kwiecien, O., Djamali, M., and Litt, T.: Vegetation and environmental changes during the last interglacial in eastern Anatolia (Turkey): a new high-resolution pollen record from Lake Van, Palaeogeogr. Palaeocl., 145-158, https://doi.org/10.1016/j.palaeo.2015.06.015, 2015a.

Pickarski, N., Kwiecien, O., Langgut, D., and Litt, T.: Abrupt climate and vegetation variability of eastern Anatolia during the last glacial, Clim. Past, 11, 1491-1505, https://doi.org/10.5194/cp11-1491-2015, 2015b.

Punt, W.: The Northwest European Pollen Flora, Elsevier, Amsterdam, 1976.

Rasmussen, S. O., Bigler, M., Blockley, S. P., Blunier, T., Buchardt, S. L., Clausen, H. B., Cvijanovic, I., Dahl-Jensen, D., Johnsen, S. J., Fischer, H., Gkinis, V., Guillevic, M., Hoek, W. Z., Lowe, J. J., Pedro, J. B., Popp, T., Seierstad, I. K., Steffensen, J. P., Svensson, A. M., Vallelonga, P., Vinther, B. M., Walker, M. J. C., Wheatley, J. J., and Winstrup, M.: A stratigraphic framework for abrupt climatic changes during the Last Glacial period based on three synchronized Greenland ice-core records: refining and extending the INTIMATE event stratigraphy, Quaternary Sci. Rev., 106, 14-28, https://doi.org/10.1016/j.quascirev.2014.09.007, 2014.

Reilinger, R., McClusky, S., Vernant, P., Lawrence, S., Ergintav, S., Cakmak, R., Ozener, H., Kadirov, F., Guliev, I., Stepanyan, R., Nadariya, M., Hahubia, G., Mahmoud, S., Sakr, K., ArRajehi, A., Paradissis, D., Al-Aydrus, A., Prilepin, M., Guseva, T., Evren, E., Dmitrotsa, A., Filikov, S. V., Gomez, F., Al-Ghazzi, R., and Karam, G.: GPS constraints on continental deformation in the Africa-Arabia-Eurasia continental collision zone and implications for the dynamics of plate interactions, J. Geophys. Res., 111, 1-26, https://doi.org/10.1029/2005JB004051, 2006.

Reille, M.: Pollen et spores d'Europe et d'Afrique du Nord, Laboratoire de Botanique Historique et Palynologie, Marseille, 1999.

Reille, M.: Pollen et spores d'Europe et d'Afrique du Nord (Supplement 2), Laboratoire de Botanique Historique et Palynologie, Marseille, 1998.

Reille, M.: Pollen et spores d'Europe et d'Afrique du Nord (Supplement 1), Laboratoire de Botanique Historique et Palynologie, Marseille, 1995.

Reille, M., de Beaulieu, J., Svobodova, H., Andrieu-Ponel, V., and Goeury, C.: Pollen analytical biostratigraphy of the last five climatic cycles from a long continental sequence from the Velay region (Massif Central, France), J. Quaternary Sci., 15, 665-685, 2000.

Roberts, N., Jones, M. D., Benkaddour, A., Eastwood, W. J., Filippi, M. L., Frogley, M. R., Lamb, H. F., Leng, M. J., Reed, J. M., Stein, M., Stevens, L., Valero-Garcés, B., and Zanchetta, G.: Stable isotope records of Late Quarternary climate and hydrology from Mediterranean lakes: the ISOMED synthesis, Quarternary Sci. Rev., 27, 2426-2441, https://doi.org/10.1016/j.quascirev.2008.09.005, 2008.

Roucoux, K. H., Tzedakis, P. C., Frogley, M. R., Lawson, I. T., and Preece, R. C.: Vegetation history of the 
marine isotope stage 7 interglacial complex at Ioannina, NW Greece, Quaternary Sci. Rev., 27, 1378-1395, https://doi.org/10.1016/j.quascirev.2008.04.002, 2008.

Roucoux, K. H., Tzedakis, P. C., Lawson, I. T., and Margari, V.: Vegetation history of the penultimate glacial period (Marine isotope stage 6) at Ioannina, north-west Greece, J. Quaternary Sci., 26, 616-626, https://doi.org/10.1002/jqs.1483, 2011.

Sadori, L., Koutsodendris, A., Panagiotopoulos, K., Masi, A., Bertini, A., Combourieu-Nebout, N., Francke, A., Kouli, K., Joannin, S., Mercuri, A. M., Peyron, O., Torri, P., Wagner, B., Zanchetta, G., Sinopoli, G., and Donders, T. H.: Pollen-based paleoenvironmental and paleoclimatic change at Lake Ohrid (south-eastern Europe) during the past $500 \mathrm{ka}$, Biogeosciences, 13, 1423-1437, https://doi.org/10.5194/bg-13-1423-2016, 2016.

Sánchez Goñi, M. F., Eynaud, F., Turon, J. L., and Shackleton, N. J.: High resolution palynological record off the Iberian margin: direct land-sea correlation for the Last Interglacial complex, Earth Planet. Sc. Lett., 171, 123-137, https://doi.org/10.1016/S0012821X(99)00141-7, 1999.

Sánchez Goñi, M. F., Cacho, I., Turon, J.-L., Guiot, J., Sierro, F. J., Peypouquet, J.-P., Grimalt, J. O., and Shackleton, N. J.: Synchroneity between marine and terrestrial responses to millennial scale climatic variability during the last glacial period in the Mediterranean region, Clim. Dynam., 19, 95-105, https://doi.org/10.1007/s00382-001-0212-x, 2002.

San-Miguel-Ayanz, J., de Rigo, D., Caudullo, G., Houston Durrant, T., and Mauri, A.: European Atlas of Forest Tree Species, Publication Office of the European Union, Luxembourg, 2016.

Shackleton, N. J., Hall, M. A., and Vincent, E.: Phase relationships between millennial-scale events 64000 24000 years ago, Paleoceanography, 15, 565-569, https://doi.org/10.1029/2000PA000513, 2000.

Shackleton, N. J., Sánchez-Goñi, M. F., Pailler, D., and Lancelot, Y.: Marine Isotope Substage 5e and the Eemian Interglacial, The eemian interglacial: a global perspective, Gloabl Planet. Change, 36, 151-155, https://doi.org/10.1016/S0921-8181(02)00181-9, 2003.

Shumilovskikh, L. S., Tarasov, P., Arz, H. W., Fleitmann, D., Marret, F., Nowaczyk, N., Plessen, B., Schlütz, F., and Behling, $\mathrm{H}$.: Vegetation and environmental dynamics in the southern Black Sea region since $18 \mathrm{kyr} \mathrm{BP}$ derived from the marine core 22-GC3, Palaeogeogr. Palaeocl., 337-338, 177-193. https://doi.org/10.1016/j.palaeo.2012.04.015, 2012.

Stockhecke, M., Kwiecien, O., Vigliotti, L., Anselmetti, F. S., Beer, J., Çağatay, M. N., Channell, J. E. T., Kipfer, R., Lachner, J., Litt, T., Pickarski, N., and Sturm, M.: Chronostratigraphy of the 600,000 year old continental record of Lake Van (Turkey), Quaternary Sci. Rev., 104, 8-17, https://doi.org/10.1016/j.quascirev.2014.04.008, 2014a.

Stockhecke, M., Sturm, M., Brunner, I., Schmincke, H.-U., Sumita, M., Kipfer, R., Cukur, D., Kwiecien, O., and Anselmetti, F. S.: Sedimentary evolution and environmental history of Lake Van (Turkey) over the past 600000 years, Sedimentology, 61, 18301861, https://doi.org/10.1111/sed.12118, 2014b.

Stockhecke, M., Timmermann, A., Kipfer, R., Haug, G.H., Kwiecien, O., Friedrich, T., Menviel, L., Litt, T., Pickarski, N., and Anselmetti, F. S.: Millennial to orbital-scale variations of drought intensity in the East- ern Mediterranean, Quaternary Sci. Rev., 133, 77-95, https://doi.org/10.1016/j.quascirev.2015.12.016, 2016.

Stockmarr, J.: Tablets with spores used in absolute pollen analysis, Pollen et Spores, 13, 615-621, 1971.

Thouveny, N., Carcaillet, J., Moreno, E., Leduc, G., and Nérini, D.: Geomagnetic moment variation and paleomagnetic excursions since 400 kyr BP: a stacked record from sedimentary sequences of the Portuguese margin, Earth Planet. Sc. Lett., 219, 377-396, https://doi.org/10.1016/S0012-821X(03)00701-5, 2004.

Turner, R., Roberts, N., Eastwood, W. J., Jenkins, E., and Rosen, A.: Fire, climate and the origins of agriculture: micro-charcoal records of biomass burning during the last glacial-interglacial transition in Southwest Asia, J. Quaternary Sci., 25, 371-386, https://doi.org/10.1002/jqs.1332, 2010.

Tzedakis, P. C.: Hierarchical biostratigraphical classification of long pollen sequences, J. Quaternary Sci., 9, 257-259, https://doi.org/10.1002/jqs.3390090306, 1994.

Tzedakis, P. C.: Towards an understanding of the response of southern European vegetation to orbital and suborbital climate variability, Quaternary Sci. Rev., 24, 1585-1599, https://doi.org/10.1016/j.quascirev.2004.11.012, 2005.

Tzedakis, P. C.: Seven ambiguities in the Mediterranean palaeoenvironmental narrative, Quaternary Sci. Rev., 26, 2042-2066, https://doi.org/10.1016/j.quascirev.2007.03.014, 2007.

Tzedakis, P. C., Andrieu, V., de Beaulieu, J.-L., Crowhurst, S., Follieri, M., Hooghiemstra, H., Magri, D., Reille, M., Sadori, L., Shackleton, N. J., and Wijmstra, T. A.: Comparison of terrestrial and marine records of changing climate of the last 500000 years, Earth Planet. Sc. Lett., 150, 171-176, 1997.

Tzedakis, P. C., Andrieu, V., de Beaulieu, J.-L., Birks, H. J. B., Crowhurst, S., Follieri, M., Hooghiemstra, H., Magri, D., Reille, M., Sadori, L., Shackleton, N. J., and Wijmstra, T. A.: Establishing a terrestrial chronological framework as a basis for biostratigraphical comparisons, European Quaternary Biostratigraphy, 20, 1583-1592, 2001.

Tzedakis, P. C., Lawson, I. T., Frogley, M. R., Hewitt, G. M., and Preece, R. C.: Buffered Tree Population Changes in a Quaternary Refugium: Evolutionary Implications, Science, 297, 2044-2047, https://doi.org/10.1126/science.1073083, 2002.

Tzedakis, P. C., Frogley, M. R., and Heaton, T. H. E.: Last Interglacial conditions in southern Europe: evidence from Ioannina, northwest Greece, Global Planet. Change, 36, 157-170, https://doi.org/10.1016/S0921-8181(02)00182-0, 2003a.

Tzedakis, P. C., McManus, J. F., Hooghiemstra, H., Oppo, D. W., and Wijmstra, T. A.: Comparison of changes in vegetation in northeast Greece with records of climate variability on orbital and suborbital frequencies over the last 450?000 years, Earth Planet. Sc. Lett., 212, 197-212, https://doi.org/10.1016/S0012821X(03)00233-4, $2003 \mathrm{~b}$.

Tzedakis, P. C., Hooghiemstra, H., and Palike, H.: The last 1.35 million years at Tenaghi Philippon: revised chronostratigraphy and long-term vegetation trends, Critical Quaternary Stratigraphy, 25, 3416-3430, https://doi.org/10.1016/j.quascirev.2006.09.002, 2006.

Van Zeist, W. and Bottema, S.: Late Quaternary vegetation of the Near East, Beihefte zum Tübinger Atlas des Vorderen Orients 18, 11-156, 1991.

Vigliotti, L., Channell, J. E. T., and Stockhecke, M.: Paleomagnetism of Lake Van sediments: chronology and paleoen- 
vironment since 350 ka, Quaternary Sci. Rev., 104, 18-29, https://doi.org/10.1016/j.quascirev.2014.09.028, 2014.

Walker, M., Johnsen, S., Rasmussen, S. O., Popp, T., Steffensen, J. P., Gibbard, P., Hoek, W., Lowe, J., Andrews, J., Björck, S., Cwynar, L. C., Hughen, K., Kershaw, P., Kromer, B., Litt, T., Lowe, D. J., Nakagawa, T., Newnham, R., and Schwander, J.: Formal definition and dating of the GSSP (Global Stratotype Section and Point) for the base of the Holocene using the Greenland NGRIP ice core, and selected auxiliary records, J. Quaternary Sci., 24, 3-17, 2009.

Wick, L., Lemcke, G., and Sturm, M.: Evidence of Lateglacial and Holocene climatic change and human impact in eastern Anatolia: high resolution pollen, charcoal, isotopic and geochemical records from the laminated sediments of Lake Van, Holocene 13, 665-675, https://doi.org/10.1191/0959683603hl653rp, 2003.

Wolff, E. W., Chappellaz, J., Blunier, T., Rasmussen, S. O., and Svensson, A.: Millennial-scale variability during the last glacial: The ice core record, Quarternary Sci. Rev., 29, 2828-2838, https://doi.org/10.1016/j.quascirev.2009.10.013, 2010.

Zohary, M.: Geobotanical Foundations of the Middle East, Gustav Fischer Verlag, Swets \& Zeitlinger, Stuttgart, Amsterdam, 1973.
Zonneveld, K. A. F., Marret, F., Versteegh, G. J. M., Bogus, K., Bonnet, S., Bouimetarhan, I., Crouch, E., de Vernal, A., Elshanawany, R., Edwards, L., Esper, O., Forke, S., Grøsfjeld, K., Henry, M., Holzwarth, U., Kielt, J.-F., Kim, S.Y., Ladouceur, S., Ledu, D., Chen, L., Limoges, A., Londeix, L., Lu, S.-H., Mahmoud, M. S., Marino, G., Matsouka, K., Matthiessen, J., Mildenhal, D.C., Mudie, P., Neil, H.L., Pospelova, V., Qi, Y., Radi, T., Richerol, T., Rochon, A., Sangiorgi, F., Solignac, S., Turon, J.-L., Verleye, T., Wang, Y., Wang, Z., and Young, M.: Atlas of modern dinoflagellate cyst distribution based on 2405 data points, Rev. Palaeobot. Palyno., 191, 1197, https://doi.org/10.1016/j.revpalbo.2012.08.003, 2013.

Zonneveld, K. A. F. and Pospelova, V.: A Determination Key for Modern Dinoflagellate Cysts, Palynology, 39, 387-409, https://doi.org/10.1080/01916122.2014.990115, 2015. 